\title{
The Economic Effect of Sentiment
}

\author{
December 20, 2010
}

\begin{abstract}
There has long been interest in the effect of changes in 'animal spirits'. The paper uses a differences-in-differences approach to estimate the macroeconomic effect of sentiment, comparing periods of high and low sentiment, making use of cross-sectional differences. Sentiment is measured using the Baker-Wurgler (2006) sentiment index. We estimate the effect of sentiment on intertemporal tradeoffs. We obtain statistically precise estimates of the effect of sentiment. Low sentiment leads agents to discount future payoffs more heavily. The estimated effects are large (600 basis points). High sentiment induces overinvestment for some firms; low sentiment induces underinvestment for other firms.
\end{abstract}

Keywords: Sentiment, financial markets, financial markets and the real economy, animal spirits, financial market imperfections, discount rates, high sentiment discount, external finance premium, finance constraints, capital stock, investment

JEL codes: E44, E32, E22, G12, G31, G32

Professor Huntley Schaller

Princeton University

Department of Economics

107 Fisher Hall

Princeton, NJ 08544-1021

Email: hschalle@Princeton.edu

Tel: 609-258-9514

I would like to thank Mark Blanchette for outstanding research assistance and the SSHRC for financial support. 


\section{Introduction}

For many decades, there has been interest in the effect on the economy of changes in the public mood - what Keynes famously referred to as "animal spirits." Much of the focus has been on investor sentiment. ${ }^{1}$ In this paper, we present econometric estimates of the effect of sentiment on discount rates.

A variety of recent theoretical work -- including Caballero, Farhi, and Hammour (2006), Farhi and Tirole (2008), and Jermann and Quadrini (2007) -- suggests that interactions between sentiment and other financial market imperfections could have important macroeconomic implications. The themes of these papers include an effect of sentiment on asset prices, the relaxation of finance constraints when asset prices are high, and a link between sentiment and liquidity. Our empirical evidence on the effect of sentiment on discount rates is closely related to this work.

Rietz (1988) and Barro (2006) show that it is possible to explain several key asset pricing puzzles in terms of the possibility of rare disasters. Gabaix (2008) and Farhi and Gabaix (2008) show that, with time-varying intensity of disasters, it is possible to explain a wide range of asset pricing puzzles. As Gabaix (2008) points out, "changing beliefs about the intensity of possible disasters are very close to what the behavioral literature calls 'animal spirits.'" To the extent that one can interpret beliefs about possible disasters (including financial crises) as sentiment -- or vice versa -- our results on the relationship between sentiment and discount rates provide an entirely new set of empirical facts for theorists to consider. This new set of facts may be useful in distinguishing between rare-disaster models and competing models, such as Campbell and Cochrane (1999) and Bansal and Yaron (2004), and in refining both rare-disaster and other models.

It has long been argued that high sentiment might translate into "irrational exuberance" that would lead to asset price bubbles, lax credit standards, overinvestment, and an eventual crash when the bubble bursts. Historically, some accounts of the Great Depression and the enormous run-up in the Nikkei in the late 1980s (followed by a decade of economic stagnation) involve these elements.

It has been less widely recognized that low sentiment might have important macroeconomic implications. An exception is Stein (1996), who carefully models the

\footnotetext{
${ }^{1}$ For work on consumer sentiment, see Lorenzoni (2008) and further references cited there.
} 
implications of sentiment for the financing and investment decisions of firms. Using Stein's model as a basis for their work, Baker, Stein, and Wurgler (2003) provide empirical evidence that sentiment has a significant effect on equity-dependent firms.

We examine the effect of sentiment on intertemporal trade-offs. In Stein's model, some agents have rational forecasts $\mathrm{EF}$ of a future variable $\mathrm{F}$, while other agents have forecasts that are influenced by sentiment: $F^{b} \equiv(1+\delta) E F$, where $\delta<0$ represents low sentiment in Stein's notation. The Stein model shows that low sentiment can lead agents to discount future payoffs more heavily. We believe our paper is the first to directly estimate the effect of sentiment on discount rates that is predicted by the Stein model. ${ }^{2}$

We measure sentiment using the sentiment index constructed by Baker and Wurgler (2006). Drawing on recent research (particularly in financial economics), Baker and Wurgler identify six proxies for investor sentiment - the closed end fund discount, turnover, the number of initial public offerings, average first-day returns on initial public offerings, the share of equity issues in total equity and debt issues, and the dividend premium. They use principal component analysis to develop a parsimonious sentiment index (at annual frequency).

We use a differences-in-differences approach to estimating the effects of sentiment. We compare economic behavior between periods of high and low sentiment and make use of crosssectional differences between agents to draw inferences about the role of sentiment.

In examining the macroeconomic implications of sentiment, we focus on the most volatile component of aggregate output and the component that has most often been associated with business cycle fluctuations - investment. Investment is important for a variety of reasons. In the neoclassical growth model, the capital/labor ratio is one of the main determinants of per capita output. In some endogenous growth models, the level of the capital stock can also affect

\footnotetext{
${ }^{2}$ Our framework fits naturally with the Stein model, but other mechanisms, such as collateral, could play a role. Higher asset prices tend to increase the value of collateral and to relax borrowing constraints, leading to a lower shadow cost of finance. For a model in which this mechanism plays an important role, see, e.g., Kiyotaki and Moore (1997). Another possible mechanism involves the effect of sentiment on growth expectations. To see this, let $X_{t}$ represent the current value of a variable (e.g., a dividend or the marginal product of capital). The expected present value of $X_{t+1}$ can be represented as

$$
(1+g) /(1+r) X_{t} \cong 1 /(1+r-g) X_{t},
$$

where $g$ is the anticipated growth rate. To a first approximation, an increase in $g$ or a decrease in $r$ have the same effect. Barberis, Shleifer, and Vishny (1998) provide a model of extrapolative expectations that could account for fluctuations in sentiment and that provides a unified account of underreaction and overreaction of asset prices to news.
} 
the rate of growth. In periods of rapid technological change, investment may play an important part in the introduction of new technology into production. Finally, recent research in macroeconomics suggests that investment-specific shocks play a key role in aggregate fluctuations. ${ }^{3}$

In Section 3, we start from a neoclassical model of investment (allowing for adjustment frictions). The first-order conditions for the model imply that a firm will make an optimal intertemporal trade-off between the costs and benefits of a marginal investment. ${ }^{4}$ The relative weight on present and future depends on the firm's discount rate, which can be thought of as the hurdle rate for investment projects. In Section 6, we estimate the intertemporal trade-off (the investment Euler equation), allowing sentiment to affect the hurdle rate. We also allow the firm's hurdle rate to depart from the risk-adjusted interest rate due to finance constraints. Ours is a revealed preference approach in the sense that it uses the behavior of the firm - i.e., the firm's investment decisions - to estimate the implicit hurdle rate that is used by the firm (rather than statements by agents, such as responses to a survey).

The paper is organized as follows. Section 2 presents an analysis of supply and demand in the market for investment funds that illustrates the potential effects of a shift in sentiment. Section 3 provides a simple model of the firm's optimization problem. The purpose of this section is to derive the empirical specification and show how finance constraints and sentiment can be incorporated into the firm's intertemporal tradeoff. Section 4 provides details on specification issues. Section 5 briefly describes the data. More detail is provided in the Data Appendix. Section 6 reports the main empirical results. Section 7 examines patterns of external finance. Section 8 calculates the distortions in the capital stock that arise from the high sentiment discount and the external finance premium. In light of recent events in financial markets, it may be interesting to focus more closely on the macroeconomic effect of low sentiment; Section 9 provides a brief discussion and empirical estimates. Section 10 summarizes the results and discusses implications.

\footnotetext{
${ }^{3}$ See, e.g., Fisher (2006).

${ }^{4}$ There is an interesting literature that examines whether stock price misvaluation affects investment. Our paper does not fit neatly into that literature, since we examine whether sentiment affects discount rates, not whether misvaluation affects investment, but these questions may be linked. The papers include Barro (1990), Blanchard, Rhee, and Summers (1993), Bond and Cummins (2000), Chirinko and Schaller (1996, 2001, 2004), Galeotti and Schiantarelli (1994), Gilchrist, Himmelberg, and Huberman (2005), Lamont (2000), Morck, Shleifer, and Vishny (1990), Panageas (2003), and Polk and Sapienza (2008). Baker, Ruback, and Wurgler (2004) provide a survey.
} 


\section{Finance Constraints, Sentiment, and Investment}

In this section, we use two diagrams to illustrate the effect of sentiment on the discount rate and investment. To keep the analysis simple, we focus on a one-period model, so that investment and the capital stock are the same. This allows us to emphasize the discount rate. ${ }^{5}$ At the end of this section, after explaining the diagrams and using them to illustrate the effects of a shift in sentiment, we explain how our diagrams capture some of the key elements of Stein (1996), the leading model of firm investment and financing decisions when the firm's stock price may be affected by investor sentiment.

In Figure 1, we illustrate the case of low sentiment. The vertical axis shows the actual discount rate used by the firm in choosing investment. The actual discount rate is denoted by $r+\mu$, where $r$ is the correctly risk-adjusted interest rate. $\mu$ is defined as the actual discount rate used by the firm minus the correctly risk-adjusted interest rate. We will refer to $\mu$ as the wedge between the firm's discount rate and the risk-adjusted interest rate - or simply as the "wedge". In the Modigliani-Miller world, $\mu=0$. Once we allow for asymmetric information problems along the lines of Akerlof (1970) or Stiglitz and Weiss (1981), firms may face finance constraints. This is represented by the vertical portion of the supply curve. The vertical portion coincides with $F^{I}$, the funds (specifically, internal funds) available to the firm. If a firm faces finance constraints (i.e., cannot borrow at rate $r$ ), there will be a difference between the shadow discount rate and $r$. The upward-sloping portion of the supply curve can be thought of as the external finance schedule. ${ }^{6}$ The effective supply curve for the firm is shown as a black solid line labeled $S^{L S}$. It is horizontal up to the point at which the firm exhausts its internal finance $F^{I}$, since the firm can always lend at $r$, so $r$ is the opportunity cost of funds. There is a vertical portion of the supply curve from the discount rate $r$ to the cheapest discount rate at which the firm can obtain external finance. The full upward-sloping external finance schedule extends to the vertical axis. The portion shown as a grey dashed line is not directly relevant, since, for

\footnotetext{
${ }^{5}$ A similar analysis could be carried out for an infinite horizon problem with convex adjustment costs, in which case the firm's problem is necessarily dynamic. In this case, we could put q on the vertical axis, and the investment demand curve would show q as a function of investment. See Fazzari, Hubbard, and Petersen (1988) for an example. This approach can be very useful, but it tends to obscure the role of the discount rate.

${ }^{6}$ Myers and Majluf (1984) present a model in which asymmetric information between firms and potential investors leads to an external finance premium. For simplicity, we do not distinguish between debt and equity as sources of external financing, but an upward sloping portion of the supply curve could also be justified for debt finance. See, e.g., Fazzari, Hubbard, and Petersen (1988) for a discussion.
} 
points to the left of $F^{I}$, internal finance is cheaper, but this portion of the external finance schedule would form part of the supply curve for a firm with less internal finance (i.e., for a firm with $F^{I}$ to the left of the level illustrated in Figure 1). This portion of the external finance schedule would also be relevant if the external finance schedule shifted down far enough so that external finance was cheaper than internal finance.

The firm's finance demand curve is equal to the marginal product of capital schedule. Two demand curves are illustrated in Figure 1. $D_{G}$ is the demand curve for a firm with good investment opportunities. $D_{P}$ is the demand curve for a firm with (relatively) poor investment opportunities. At any given level of investment, the marginal product of capital is higher for the firm with good investment opportunities.

In the Modigliani-Miller world, both firms would set the marginal product of capital equal to $r$. For the firm with good investment opportunities, this implies unconstrained, firstbest investment of $I_{G}^{*}$. We assume both firms have internal finance $F^{I}$. Since $I_{G}^{*}>F^{I}$, in the Modigliani-Miller world, the firm with good investment opportunities would obtain external finance for the difference $I_{G}^{*}-F^{I}$. For the firm with poor investment opportunities, the optimal level of investment is $I_{P}^{*}$. This firm would have excess funds $F^{I}-I_{P}^{*}$ available that it could lend (or it could pay out dividends or make share repurchases).

In models with asymmetric information between the insiders in the firm and potential suppliers of finance (e.g., the Myers-Majluf (1984) model), there is an external finance premium. $^{7}$ In the case illustrated in Figure 1, this implies that the shadow discount rate for the firm with good investment opportunities is $r+\mu_{G}$. Because the firm is unable to borrow freely at rate $r$, its constrained, second-best investment level is $I_{G}^{L S}$, which is equal to the amount of internal finance available. In both the supply curve and $I_{G}^{L S}, L S$ is used to denote a low sentiment episode.

Figure 2 illustrates the effects of a shift in sentiment. The old level of sentiment is shown in grey. The new, higher level of sentiment is reflected in the downward shift in the supply

\footnotetext{
${ }^{7}$ There is a large literature on the implications of finance constraints for the aggregate economy. See, e.g., Bernanke and Gertler (1989), Bernanke, Gertler, and Gilchrist (1999), and Kiyotaki and Moore (1997).
} 
curve. In the case illustrated in Figure 2, the shift in sentiment is sufficiently large that equity finance is available at a rate that is below $r$ over some range.

Caballero, Farhi, and Hammour (2006, p. 1162) suggest that, "some of these companies (in the 1990s) were undoubtedly bubbles and crowded out capital from good firms, but many others were pillars of the information technology revolution that was so central to the episode." They discuss the possibility that speculative episodes may be associated with a relaxation of finance constraints. ${ }^{8}$ In their model, a low cost of capital is associated with the speculative equilibrium. Jermann and Quadrini (2007) provide a model in which high asset prices could relax finance constraints and allow otherwise constrained firms to increase their investment. ${ }^{9}$

Figure 2 illustrates both of the possibilities discussed by Caballero, Farhi, and Hammour (2006), that: 1) speculative episodes could be associated with a relaxation of finance constraints and a lower cost of capital; and 2) high sentiment could induce low discount rates and distorted investment.

First, consider finance constraints. Figure 2 illustrates the case in which the shift in sentiment allows the firm with good investment opportunities to achieve its optimal, first-best investment $I_{G}^{*}$ through cheap external financing (cheap, that is, compared to an episode of low sentiment).

Second, consider potential investment distortions. Figure 2 illustrates the case where the shift in sentiment makes equity financing appear sufficiently cheap to induce the firm with poor investment opportunities to invest $I_{P}^{H S}$. This level of investment exceeds the first-best (evaluated at $r$ ) by $I_{P}^{H S}-I_{P}^{*}$. In this case, the firm's discount rate $r+\mu_{P}$ is lower than the risk-adjusted interest rate $r$, so the wedge $\mu_{P}$ is negative. We will refer to a negative value of $\mu$ that arises due to an episode of high sentiment as a "high sentiment discount."

Our empirical approach, which is described in Section 4, allows for $\mu \neq 0$. More precisely, it allows us to estimate $\mu$ and compare $\mu$ across episodes of low and high sentiment, firms with greater or lesser sensitivity to sentiment, and firms with good versus poor investment opportunities.

\footnotetext{
${ }^{8}$ Caballero, Farhi, and Hammour (2006) model "rational bubbles". Another possible approach is to incorporate behavioral biases and limits to arbitrage; for a model that captures many features of historical speculative episodes, see Scheinkman and Xiong (2003).

${ }^{9}$ Olivier (2000) provides a model in which speculative bubbles on equity raise the market value of firms and encourage investment.
} 
In Figure 2, we assume that the shift in sentiment only affects the supply curve for finance, not the demand curves. This is consistent with the Stein model, in which the manager's forecast of future variables is rational (and unbiased), but the forecasts of outside shareholders are influenced by sentiment (and biased). It is also consistent with the approach to the firm's problem described in the next section, in which we treat the firm as a fully rational agent that solves an infinite horizon optimization problem. Under this scenario, the demand curves in Figure 2 are simply the marginal product of capital schedules and are not affected by sentiment. ${ }^{10}$

The diagrammatic exposition in Figures 1 and 2 is simple and intuitive, but it manages to capture some key aspects of Stein (1996). First, Stein shows that sentiment can affect the firm's discount rate. Specifically, sentiment can lead to a discount rate that is above or below $\mathrm{r}$. In Stein's notation, the firm's discount rate can correspond to CER and CER can be less than $k^{*}$ when $\delta>0$, where CER is the best estimate of the firm's conditional expected return, $k^{*}$ is the correctly risk-adjusted interest rate, and $\delta$ is a parameter that captures how much sentiment pushes the firm's stock price above or below the sentiment-free price. In Stein's model, sentiment can affect the discount rate due to short horizons on the part of the firm's manager (e.g., due to rapid turnover in the firm's shareholders) or finance constraints. (We will return to the issue of finance constraints in Stein's model in a moment.) Polk and Sapienza (2008) present a model in which catering on the part of the firm's manager provides another channel which sentiment can affect intertemporal decisions. Second, in Stein's model, finance constraints matter. More precisely, he introduces a cost $Z(L)$ of deviating from the optimal capital structure. For unconstrained firms, $d Z / d L=0$. Third, in his model, when sentiment is low, the discount rate will be higher than $r$ for finance constrained firms. This is shown in Stein's propositions 5 and 6 , which derive the result that the firm's discount rate will be greater than $k^{*}$ when $\delta<0$. Fourth, Stein shows that finance constrained firms are more likely to be affected by sentiment. (In Figures 1 and 2, this is captured by the fact that shifts in sentiment can affect constrained -- but not unconstrained -- firms when the upward-sloping portion of the supply curve is above the point $\left(F^{I}, r\right)$.) Fifth, in the Stein model, sentiment can affect the discount

\footnotetext{
${ }^{10}$ Our empirical approach is more agnostic. The estimated value of $\mu$ reflects the intertemporal tradeoff made by the firm, regardless of whether this is due to an exogenous shift in the finance supply curve or a demand-side effect of sentiment on the firm's intertemporal choices. For empirical evidence on whether firm managers are subject to behavioural biases, such as overconfidence, see, e.g., Malmendier and Tate (2005).
} 
rate for firms that are not finance constrained (if the firm's objective is to maximize the current stock price). ${ }^{11}$ Sixth, in the Stein model, the external finance supply curve may slope upwards. In his model, this occurs because equity issues can have a negative affect on the firm's stock price. Specifically, his model incorporates a function $i(E)$ that captures the price-impact-related losses associated with an equity transaction of size $\mathrm{E}$, with the restriction that $d i / d E \geq 0$ for $E>0$ (new equity issues) and $d i / d E \leq 0$ for $E<0$ (repurchases). The Stein model offers a richer analysis than Figures 1 and 2, but the figures may provide a simple and helpful framework that is broadly consistent with the Stein model.

\section{Firm's Problem}

\subsection{No Finance Constraints and No Sentiment}

The objective of the firm is to maximize its value, $V_{0}$, as of period 0 :

$$
V_{0}=E_{0} \sum_{t=1}^{\infty}\left(\prod_{j=0}^{t-1} \beta_{j}\right) d_{t},
$$

where $E_{0}$ is the expectations operators conditional on information available at time $0, \beta_{j}$ is the discount factor at time $t$ (or the inverse of one plus the discount rate), and $d_{t}$ is dividends. The firm faces a capital accumulation constraint that

$$
K_{t}=(1-\delta) K_{t-1}+I_{t},
$$

where $K_{t}$ is the capital stock at the end of period $t, \delta$ is the depreciation rate, and $I_{t}$ is investment. The firm also faces a non-negativity constraint on dividends,

$$
d_{t} \geq 0 \forall t
$$

with $d_{t}$ defined as

$$
\left(\Pi\left(K_{t-1}, L_{t}\right)-G\left(I_{t}, K_{t-1}\right)-w_{t} L_{t}\right)-p_{t}^{I} I_{t}+B_{t}-\left(1+r_{t-1}\right) B_{t-1},
$$

\footnotetext{
${ }^{11}$ Stein calls this the "short-horizon" case, since it corresponds to a situation in which the firm's choices benefit shareholders who sell their stock soon at the expense of long-term shareholders.
} 
where $\Pi\left(K_{t-1}, L_{t}\right)$ is the revenue function, $L_{t}$ is variable inputs, and $w_{t}$ and $p_{t}^{I}$ are the real price of variable inputs and investment, respectively. It is assumed that capital is costly to adjust, and $G\left(I_{t}, K_{t-1}\right)$ is a linear homogenous function in $I$ and $K$. The firm pays $r_{t-1}$, the real interest rate, on the stock of one-period external finance outstanding at the end of period $t-1$ and issues an amount $B_{t}$ of new external finance each period, subject to the transversality condition that

$$
\lim _{T \rightarrow \infty}\left(\prod_{t=0}^{T-1} \beta_{t}\right) B_{T}=0
$$

Let $\lambda_{t}^{K}$ and $\lambda_{t}^{d}$ be the Lagrange multipliers on capital accumulation and the nonnegativity constrain on dividends, respectively. Let $H_{x}$ denote the partial derivative of the function $\mathrm{H}$ with respect to $x$. The first order conditions for capital, investment, and debt are, respectively:

$$
\begin{gathered}
-\lambda_{t}^{K}+\left(1+\lambda_{t+1}^{d}\right) \beta_{t}\left(\Pi_{K}\left(K_{t}, L_{t+1}\right)-G_{K}\left(I_{t+1}, K_{t}\right)\right)+E_{t} \beta_{t}(1-\delta) \lambda_{t+1}^{K}=0, \\
\lambda_{t}^{K}=\left(1+\lambda_{t}^{d}\right)\left(p_{t}^{I}+G_{I}\left(I_{t}, K_{t-1}\right)\right), \\
\left(1+\lambda_{t}^{d}\right)-E_{t}\left[\left(1+\lambda_{t+1}^{d}\right) \beta_{t}\left(1+r_{t}\right)\right]=0 .
\end{gathered}
$$

The first order conditions imply the following investment Euler equation:

$$
\begin{aligned}
& E_{t}\left[-\left(p_{t}^{I}+G_{I}\left(I_{t}, K_{t-1}\right)\right)+\left(1 /\left(1+r_{t}\right)\right) \times\right. \\
& \left.\quad\left(\Pi_{K}\left(K_{t}, L_{t+1}\right)-G_{K}\left(I_{t+1}, K_{t}\right)+(1-\delta)\left(p_{t+1}^{I}+G_{I}\left(I_{t+1}, K_{t}\right)\right)\right)\right]=0
\end{aligned}
$$

\subsection{Asymmetric Information and Finance Constraints}

Under imperfect information, insiders within the firm can either invest or divert resources and appropriate the proceeds, but the lender can never be sure whether low output is the result of 
a negative shock or mismanagement. ${ }^{12}$ The optimal financial contract is structured to minimize the gap between repayment when the project fails and when it succeeds (and thus the extent to which investment falls below its first-best level). The features of asymmetric information can be modeled as an external finance capacity constraint on the firm. If $B_{t}^{*}$ is the maximum amount of external finance that the firm is allowed to issue, then

$$
B_{t} \leq B_{t}^{*}
$$

Let $\omega_{t}$ be the Lagrange multiplier on the finance constraint. In place of (8), the first order condition for $B_{t}$ now becomes:

$$
\left(1+\lambda_{t}^{d}\right)-E\left[\beta_{t}\left(1+\lambda_{t+1}^{d}\right)\left(1+r_{t}\right)\right]-\omega_{t}=0
$$

When the finance constraint does not bind, $\omega_{t}=0$ and (11) reduces to (8), the case of symmetric information. Let $\tilde{\omega}_{t}=\omega_{t} /\left(1+\lambda_{t}^{d}\right)$ and the discount factor be $E_{t}\left[\left(\left(1+\lambda_{t}^{d}\right)\left(1-\tilde{\omega}_{t}\right)\right)\left(\left(1+\lambda_{t+1}^{d}\right)\left(1+r_{t}\right)\right)^{-1}\right]$. Equivalently, a finance constrained firm discounts the future more heavily. It follows that, when the constraint binds, the discount factor is smaller under asymmetric information than under symmetric information, ceteris paribus. If $\lambda_{t}^{d}=\lambda_{t+1}^{d}$, the discount factor is $\frac{1-\tilde{\omega}_{t}}{1+r_{t}}$.

Once we allow for asymmetric information, the investment Euler equation becomes:

$$
\begin{aligned}
& E_{t}\left[-\left(p_{t}^{I}+G_{I}\left(I_{t}, K_{t-1}\right)\right)+\left(1 /\left(1+r_{t}\right)\left(1-\tilde{\omega}_{t}\right)\right) \times\right. \\
& \left.\quad\left(\Pi_{K}\left(K_{t}, L_{t+1}\right)-G_{K}\left(I_{t+1}, K_{t}\right)+(1-\delta)\left(p_{t+1}^{I}+G_{I}\left(I_{t+1}, K_{t}\right)\right)\right)\right]=0
\end{aligned}
$$

\footnotetext{
${ }^{12}$ For a theoretical survey of asymmetric information, costly external finance, and investment, see Stein (2003); for empirical surveys, see Hubbard (1998) and Schiantarelli (1995).
} 


\subsection{Adding Sentiment}

As illustrated in Figure 2, a shift in sentiment can reduce the discount rate. In the absence of finance constraints, this implies that the discount rate would be $r_{t}+\eta\left(S_{t}\right)$, instead of $r_{t}$, where $\eta\left(S_{t}\right)$ is the high sentiment discount discussed in Section 2. Based on the analysis in Section $2, \eta\left(S_{t}\right) \leq 0$ and $\partial \eta / \partial S<0$. In other words, if high sentiment has any effect, it will be to reduce the discount rate, and the higher the level of sentiment, the lower the discount rate. When we allow for finance constraints, the discount factor becomes

$$
\frac{1-\tilde{\omega}}{1+r_{t}+\eta\left(S_{t}\right)}
$$

In other words, if the finance constraint binds, it will have the effect of raising the discount rate. Taking a first-order approximation, we can express the discount factor as

$$
\frac{1}{1+r_{t}+\tilde{\omega}_{t}+\eta\left(S_{t}\right)}=\frac{1}{1+r_{t}+\mu_{t}}
$$

where

$$
\mu_{t} \equiv \tilde{\omega}_{t}+\eta\left(S_{t}\right)
$$

This corresponds with our earlier definition of $\mu_{t}$ as the firm's discount rate minus the correctly risk-adjusted interest rate $r_{t}$. When finance constraints bind, $\mu_{t}>0$. If sentiment is sufficiently high, $\mu_{t}<0$.

Our empirical approach is to estimate the investment Euler equation, allowing $\mu_{t}$ to vary in the time series dimension depending on the Baker-Wurgler sentiment index and in the crosssectional dimension based on sensitivity to sentiment and likelihood of finance constraints.

\section{Specification issues}

We adjust the market discount rate $\left(r_{t}\right)$ for systematic risk, inflation, and taxes, as discussed in the Data Appendix. We capture the effects of unmodeled factors that affect the 
discount rate and are common to all firms with the parameter, $\psi$. We also incorporate taxes. The empirical Euler equation is

$$
\begin{aligned}
& -\left(\left(1-i t c_{t}-z_{t}\right) \tilde{p}_{t}^{I}+\left(1-\tau_{t}\right) G_{I}\left[I_{t}, K_{t}\right]\right)\left(1+r_{t}+\psi+\mu_{t} \Gamma_{t-1}\right) \\
& +\left(\left(1-\tau_{t}\right)\left(\Pi_{K, t}-G_{K, t}\right)+\left(1-\delta_{t}\right)\left(1-i t c_{t+1}-z_{t+1}\right) \tilde{p}_{t}^{I}+\left(1-\delta_{t}\right)\left(1-\tau_{t+1}\right) G_{I}\left[I_{t+1}, K_{t+1}\right]\right)=u_{t}
\end{aligned}
$$

where $i t c_{t}$ is the investment tax credit rate, $z_{t}$, is the present value of depreciation allowances per dollar of investment spending, $\tau_{t}$ is the marginal corporate income tax rate, $\tilde{p}_{t}^{I}$ is the relative price of capital goods $p_{t}^{I} / p_{t}^{Y}, p_{t}^{I}$ is the price of capital goods, $p_{t}^{Y}$ is the price of output, and $\Gamma_{\mathrm{t}-1}$ is an indicator variable. For example, $\Gamma_{t-1}$ might be set equal to 1 if the sentiment index was high in $t-1$ and the firm had characteristics associated with high sensitivity to sentiment. (We specify these characteristics in section 6.) The error term $u_{t}$ arises when we replace the expected values of variables dated $t+1$ with their realized values. We have added a time subscript to $\delta$ because we allow for time-varying depreciation rates, as described in the Data Appendix.

We assume that the marginal adjustment cost function $G_{I}\left[I_{t}, K_{t}\right]$ depends on the investment/capital ratio. We use the following first-order Taylor approximation,

$$
G_{I}\left[I_{t}, K_{t}\right]=\left(\alpha_{0}+\alpha_{1}\left(I_{t} / K_{t}\right)\right)
$$

The marginal revenue product of capital $\Pi_{K, t}-G_{K, t}$ depends on the underlying production and adjustment cost functions and product market characteristics. The production function is assumed to be homogeneous of degree $(1+\xi)$, where $\xi$ is not necessarily equal to zero. Product markets may be imperfectly competitive, and the demand schedule has a constant elasticity of $\mu$ $\geq 0$. Using Euler's Theorem on Homogeneous Functions, we obtain the following specification for the marginal revenue product of capital,

$$
\left(\Pi_{K, t}-G_{K, t}\right)=\zeta *\left(\operatorname{SALES}_{t} / K_{t}\right)-\left(\operatorname{COST}_{t} / K_{t}\right)+G_{I}\left[I_{t}, K_{t}\right] *\left(I_{t} / K_{t}\right)
$$

where $\left(S A L E S_{t} / K_{t}\right)$ and $\left(\operatorname{COST}_{t} / K_{t}\right)$ are sales revenues and variable costs, respectively, divided by the beginning-of-period capital stock, $G_{I}\left[I_{t}, K_{t}\right]$ is defined in equation (17), and $\zeta \equiv(1+\xi)(1-\mu)$, thus capturing the combined effects of non-constant returns to scale and 
imperfect competition. Decreasing returns to scale and/or non-competitive product markets imply that $\zeta<1$.

The main econometric results are based on the Euler equation (16) estimated by GMM with the following instruments: $\left(1-\tau_{t-1}\right)\left(S A L E S_{t-1} / K_{t-1}\right),\left(1-\tau_{t-1}\right)\left(I_{t-1} / K_{t-1}\right)$, $\left(1-\tau_{t-1}\right)\left(I_{t-1}^{2} / K_{t-1}^{2}\right),\left(1-\tau_{t-1}\right)\left(1+r_{f, t-1}+\delta_{, t-1}\right),\left(1-i t c_{s, t-1}-z_{s, t-1}\right) \tilde{p}_{s, t-1}^{I}$, and an indicator variable $\left(\Gamma_{\mathrm{t}-2}\right)$ identifying a class of observations, where $r_{f, t}$ is the real, risk-adjusted market discount rate for firm $f$ and $\delta_{s, t}$ is the depreciation rate for sector $s .{ }^{13}$

\section{Dataset}

The panel data consists of U.S. firms for the period 1980-2004, with data drawn from CompuStat, CRSP, and various sources of industry and aggregate data. Details are provided in the Data Appendix.

The interest rate $\left(r_{t}\right)$ is a weighted-average cost of capital (where the weights vary by sector) that accounts for both risk and taxes. The risk premium is calculated using the FamaFrench three-factor model.

Gross nominal investment is capital expenditures (CompuStat item 128). Net Sales is CompuStat item 12. Variable costs is the sum of the Cost of Goods Sold (CompuStat item 41) and Selling, General, and Administrative Expense (CompuStat item 189; when this item is not reported, it is set to zero.) The depreciation rate is allowed to vary across industries and over time and is based on BEA data. The relative price of investment is the ratio of the price of investment to the price of output. The industry-specific implicit price deflators are taken from the BEA; the relative price series is adjusted for corporate income taxes.

Table 1 presents summary statistics. For the full sample, the median ratio of investment to the capital stock is 0.073 . The median capital stock is about $\$ 70$ million (1996 dollars). As is typically the case with firm-level data, the mean capital stock is much larger - about $\$ 8.8$ billion.

\footnotetext{
${ }^{13}$ Andrews and $\mathrm{Lu}$ (2001) discuss the role of the $\mathrm{J}$ statistic in detecting correlation between the instruments and unobserved fixed effects in the error term (which, if present, could lead to inconsistent parameter estimates). As shown below in Table 2 (and other tables), the $\mathrm{J}$ statistic for the model provides no evidence of such a correlation (and the model fits better without first differencing to remove fixed effects, perhaps because of the stronger link between instruments and Euler equation variables in levels), so we do not first difference the model. Other studies, using slightly different specifications and data, find that first differencing can be useful in estimating Euler equations.
} 
The primary variable we analyze is the ratio of investment $(I)$ to the capital stock $(K)$, which is calculated using a standard perpetual inventory algorithm. There are a few extreme outliers for $I / K$ and other variables. This is a common issue in panel data studies. We address this issue by trimming the $3 \%$ tails of the following variables: $S A L E S_{t} / K_{t}, \operatorname{COST}_{t} / K_{t}$, and $I_{t} / K_{t}$.

\section{Empirical Results}

As discussed in Sections 2 and 3, the parameter $\mu_{t}$ - the wedge between the firm's discount rate and the risk-adjusted interest rate - can reflect either the external finance premium or the high sentiment discount. Our primary focus is on the effect of sentiment (although we are also interested in the interaction between sentiment and finance constraints). As discussed in Section 4 , we estimate $\mu_{t}$ as the coefficient on $\Gamma_{t-1}$, where $\Gamma_{t-1}$ is part of the specification of the discount rate, specifically an indicator variable for the level of sentiment and firm characteristics that are associated with higher sensitivity to sentiment. We follow Baker and Wurgler (2006) in defining these characteristics.

\subsection{Firm Characteristic and Sentiment}

Economic theory has long suggested that assets will be the hardest to value when it is difficult to form precise expectations of their future cash flows. ${ }^{\mathbf{1 4}}$ As Baker and Wurgler (2006, p. 1648-49) argue, "Consider a canonical young, unprofitable, extreme growth stock. The lack of an earnings history combined with the presence of apparently unlimited growth opportunities allows unsophisticated investors to defend, with equal plausibility, a wide spectrum of valuations, from much too low to much too high, as suits their sentiment. During a bubble period, when the propensity to speculate is high, this profile of characteristics also allows investment bankers (or swindlers) to further argue for the high end of valuation. By contrast, the value of a firm with a long earnings history, tangible assets, and stable dividends is much less subjective, and thus its stock is likely to be less affected by fluctuations in the propensity to speculate."

\footnotetext{
${ }^{14}$ See, for example, Blanchard and Watson (1982).
} 
Baker and Wurgler (2006) further argue that sentimental investors demand stocks that have the bundle of salient characteristics that is compatible with their sentiment. For example, investors with a low propensity to speculate may demand profitable, dividend-paying stocks because the characteristics of profitability and dividend payment define safety for these investors. Similarly, the characteristics of being young, paying no dividends, and having no earnings mark a stock as speculative. Baker and Wurgler argue that picking stocks on the basis of these types of characteristics "may be a more accurate description of how typical investors pick stocks than the process outlined by Markowitz (1959), in which investors view individual securities purely in terms of their statistical properties."

Finance theory teaches us that mispricing can be eliminated by arbitrage. The existence of sentimental investors is therefore not a sufficient condition for mispricing to exist. However, an important literature in modern finance argues that there are circumstances in which arbitrage is difficult or costly. ${ }^{15}$ Baker and Wurgler use cross-sectional differences in the costs of arbitrage as an additional way of identifying firms that are sensitive to sentiment. According to both finance theory and empirical research in finance, arbitrage is particularly risky and costly for young, small, unprofitable firms - and for extreme growth or distressed stocks. As Baker and Wurgler emphasize, stocks with these characteristics are typically more costly to trade [Amihud and Mendelsohn (1986)] and expensive or impossible to sell short [D'Avolio (2002), Geczy, Musto, and Reed (2002), Jones and Lamont (2002), Duffie, Gârleanu, and Pedersen (2002), Lamont and Thaler (2003), Mitchell, Pulvino, and Stafford (2002)]. As shown by Brunnermeier and Pedersen (2005), the low liquidity of these stocks exposes potential arbitrageurs to predatory attacks. In addition, high idiosyncratic risk makes arbitrage particularly risky [Wurgler and Zhuravskaya (2002)].

Based on these two criteria - difficulty of valuation and limits to arbitrage - Baker and Wurgler identify several categories of firms as sensitive to sentiment, including small firms, nondividend-paying firms, high volatility firms, young firms, unprofitable firms, firms with low earnings, firms with few tangible assets, and firms with "extreme" book-to-market ratios. ${ }^{16}$ Although we refer to "firms" with these characteristics, strictly speaking, these are characteristics of observations. For example, a firm might be classified as young at the beginning of our sample

\footnotetext{
${ }^{15}$ See, e.g., Shleifer and Vishny (1997).

${ }^{16}$ Compared to firms in the middle of the distribution, firms in the extreme ends of the book-to-market distribution tend to be harder to value (and Baker and Wurgler suggest, harder to arbitrage) and thus more sensitive to sentiment.
} 
but not later in the sample. Detailed definitions of each characteristic are provided in the appendix.

To evaluate their sentiment index, Baker and Wurgler test whether it has predictive power for stock returns. They argue that both theory and historical evidence suggests that high sentiment may cause overpricing. It is difficult to directly identify mispricing, so Baker and Wurgler test for systematic patterns of mispricing correction. They find that firms that are sensitive to sentiment experience predictably lower returns following episodes of high sentiment, a pattern that they argue is consistent with overpricing during episodes of high sentiment and low subsequent returns as the overpricing is corrected.

In economic theory, the motivation for finance constraints is asymmetric information. Some of the Baker-Wurgler characteristics are likely to be associated with asymmetric information. For example, because there may be fixed costs of monitoring, it has long been argued that small firms will be more subject to asymmetric information problems (and thus more likely to be finance constrained) than large firms. For young firms, there is less of a history of publicly available information, leading to a greater degree of asymmetric information than for long-established firms. For slightly different reasons, low dividend payment was the key characteristic Fazzari, Hubbard, and Petersen (1988) used in their pioneering study of finance constraints. ${ }^{17}$ Ceteris paribus, high volatility may make asymmetric information problems more severe. $^{18}$

On the other hand, not all of the Baker-Wurgler sentiment characteristics are necessarily associated with finance constraints. For example, firms may be unprofitable due to bad luck, mismanagement, or corporate governance problems.

\footnotetext{
${ }^{17}$ To see this, consider Figure 1. A firm with relatively poor investment opportunities will not exhaust its internal finance and will therefore be able to pay dividends of $F^{I}-I_{P}^{*}$. It will not be finance constrained. In contrast, a firm with good investment opportunities will exhaust its internal finance and not be in a position to pay dividends. As illustrated in Figure 1, such a firm will be finance constrained (assuming asymmetric information leads to a finance supply curve like $S^{\mathrm{LS}}$ ).

${ }^{18}$ High volatility might also increase the likelihood of a binding irreversibility constraint, which could increase the discount rate. See, e.g., Bertola and Caballero (1994), who show that, when a binding irreversibility constraint is possible, the discount rate will exceed the real interest rate by an amount that depends on the variances of the stochastic processes for demand/technology shocks and investment goods price shocks.
} 


\subsection{The Discount Rate, Sentiment, and Firm Characteristics}

Table 2 presents estimates of $\mu_{t}$ during episodes of low sentiment for firms with five of the characteristics associated with sensitivity to sentiment. (Low and high sentiment are defined as negative and positive values of the Baker-Wurgler sentiment index, respectively.) The table provides evidence that, during episodes of low sentiment, some types of firms are finance constrained. For example, the wedge $\mu_{t}$ is equal to 420 basis points for small firms during low sentiment episodes. (The standard error is 190 basis points, so the evidence of a positive $\mu_{t}$ is statistically significant.) This is consistent with the case of finance constraints illustrated in Figure 1. The results are stronger for non-dividend paying firms. During low sentiment episodes, the wedge $\mu_{t}$ is 820 basis points (with a standard error of 120 basis points). The estimate of $\mu_{t}$ is somewhat higher - about 1000 basis points - for high volatility firms and is again statistically significant. Interestingly, the estimate of $\mu_{t}$ is close to 0 for the firms with the characteristic that seems least likely to be associated with finance constraints - unprofitable firms.

It may be useful to compare the estimates of $\mu_{t}$ with previous estimates in the literature. Whited (1992) provided the first estimates of $\mu_{t}$ from an investment Euler equation estimated on US firm-level panel data. Figure 1 of her paper, which focuses on finance constraints, presents percentiles of $\mu_{t}$ for firms that are identified as finance constrained (on the basis of the fact that they do not have bond ratings). The median of $\mu_{t}$ is about 1200 basis points. The 80 th percentile is over 2000 basis points. In discussing the upper percentiles of Figure 1, Whited (page 1449) says, "This result suggests that some firms... face severe credit constraints." Using Canadian firm-level data, Chirinko and Schaller (2004, Table 4, page 199) obtain an estimate of 900 basis points, also using bond ratings to identify finance-constrained firms. The estimates in Table 2 therefore seem to be broadly consistent with (although perhaps somewhat smaller than) other estimates of $\mu_{t}$ in the literature.

Although these are not our primary focus, Table 2 presents other parameter estimates. The estimated value of $\zeta$ is around 0.9 , which is consistent with modest decreasing returns to scale and/or imperfect competition in product markets. The parameters $\alpha_{0}$ and $\alpha_{1}$ determine 
adjustment costs. Both are positive. As shown in the rows marked $G_{I}\left[I_{t}, K_{t-1}\right]$ and $G_{I I}\left[I_{t}, K_{t-1}\right]$, the estimated values of the adjustment cost parameters imply that marginal adjustment costs are positive and that the curvature of the adjustment cost function is positive. The row labeled $\mathbf{J}$ reports the test of overidentifying restrictions. The Euler equation specification is not rejected by the data. ${ }^{19}$ The final row, labeled N, reports the number of observations used in estimating each regression. The sample varies across rows (and tables) due to data limitations, but is generally in excess of 50,000 observations.

Table 3 presents tests of the effect of sentiment. The first two columns provide estimates of $\mu_{t}$ during episodes of high and low sentiment, respectively. ${ }^{20}$ The third column reports the difference in $\mu_{t}$ between high and low sentiment episodes. Table 3 provides evidence that sentiment makes an economically and statistically significant difference to discount rates for some firms. For small firms, high sentiment reduces the discount rate by 630 basis points. For non-dividend paying firms, high sentiment reduces the discount rate by 660 basis points. For high volatility firms, high sentiment reduces $\mu_{t}$ by 940 basis points. All of these differences are highly significant at the $1 \%$ level. For all the other types of sentiment-sensitive firms in Table 3 , high sentiment significantly reduces the discount rate.

\subsection{Investment Opportunities and Sentiment: Results Based on Tobin's q}

The analysis in Section 2 emphasizes the importance of investment opportunities. As shown in Figure 1, firms with good investment opportunities are more likely to face binding finance constraints, especially in periods of low sentiment. As illustrated in Figure 2, a shift to higher sentiment can relax finance constraints. This is one of the key points made by the Stein (1996) model: when a firm is finance constrained, it is more likely that sentiment will affect the firm's discount rate. This point also plays a key role in Baker, Stein, and Wurgler (2003), where the focus is on equity-dependent firms that are more likely to be affected by sentiment. Figure 2

\footnotetext{
${ }^{19}$ Euler equation specifications that do not allow for frictions (e.g., finance constraints) are frequently rejected by the data, so the J statistic normally has power in this context. See, e.g., Whited (1992).

${ }^{20}$ In Table 2, we present estimates that only include a low sentiment $\mu_{t}$, while Table 3 is based on a specification that includes both a low and high sentiment $\mu_{t}$. As a result, there are some (mostly small) differences in the point estimates of the low sentiment $\mu_{t}$ between Tables 2 and 3 .
} 
also illustrates another point: high sentiment is more likely to lead to negative values of $\mu_{t}$ for firms with poor investment opportunities than for firms with good investment opportunities. We therefore subdivide firms based on investment opportunities.

Tobin's q is a standard measure of investment opportunities. Under some circumstances, Tobin's q will be equal to marginal q (i.e., the present value of expected future marginal products of capital, evaluated at the risk-adjusted interest rate), as shown by Hayashi (1982). Besides some technical conditions, such as linear homogeneity of the production and adjustment cost functions, an important condition for this equality is that the stock market price of a firm corresponds to the expected present value of its future cash flows. Clearly, the presence of sentiment could lead to a violation of this condition.

Table 4 reports estimates of $\mu_{t}$ for periods of high and low sentiment - with each set of sentiment-sensitive firms divided between those with good and poor investment opportunities. Firms with Tobin's q above the median for the full sample are defined as having good investment opportunities, while firms with Tobin's q below the median are defined as having poor investment opportunities. Using Tobin's q as a measure of investment opportunities, the results on low sentiment episodes are somewhat mixed. In several cases, there is evidence of an external finance premium. For example, the estimate of $\mu_{t}$ is positive and significant for firms with relatively few tangible assets. But there are cases where $\mu_{t}$ is higher for firms with poor investment opportunities than firms with good investment opportunities, a result that is inconsistent with economic theory. In two other cases (small and non-dividend-paying firms), the estimates of $\mu_{t}$ are similar for firms with good and poor investment opportunities. Overall, the results for low sentiment raise questions about whether Tobin's q is a good measure of investment opportunities. We return to this point in the next subsection.

The most striking results in Table 4 are the estimates of $\mu_{t}$ for firms with poor investment opportunities during episodes of high sentiment. The estimates of $\mu_{t}$ are all negative. For small firms with poor investment opportunities, $\mu_{t}$ is -490 basis points during high sentiment episodes. In the notation introduced in Section 3.3, the high sentiment discount $\eta_{t}$ is 490 basis points. For non-dividend paying firms, the high sentiment discount is 390 basis points. For high volatility firms, $\eta_{t}$ is 680 basis points. All of these estimates are reasonably 
precise and strongly significant. For almost all categories of sentiment-sensitive firms with poor investment opportunities, there is a significant high sentiment discount. In contrast, there is little evidence of a statistically significant high sentiment discount for sentiment-sensitive firms with good investment opportunities.

\subsection{Better Measures of Investment Opportunities}

Tobin's q is a standard measure of investment opportunities, but it is fraught with problems in research that takes seriously the possibility of misvaluation. ${ }^{21}$ The problem is that the numerator of Tobin's q is the stock market value of the firm, which could be high either due to good investment opportunities or overpricing. To address this problem, we adjust Tobin's q in a way that takes into account potential misvaluation. Suppose that sentiment is high in a particular year and this pushes up stock market prices across the board. For a firm with good investment opportunities, the stock market price should rise even more because of its good investment opportunities. A similar argument applies to industries. Thus, we can partially control for the effects of misvaluation on Tobin's q by classifying firms as having good investment opportunities if their Tobin's q is high relative to other firms in their industry in a given year.

Table 5 presents estimates of $\mu_{t}$ that condition on investment opportunities using Tobin's $\mathrm{q}$ adjusted for misvaluation. The results are striking. Consider small firms as an example. In Table 4, which is based on unadjusted Tobin's q, the estimated wedge for small firms when sentiment is low is about the same regardless of whether they have good or poor investment opportunities. In Table 5, which is based on Tobin's q adjusted for misvaluation, small firms with good investment opportunities have a highly significant positive wedge in low sentiment periods. In contrast, the wedge for small firms with poor investment opportunities is essentially zero in low sentiment periods.

The estimates show that high sentiment allows small firms with good investment opportunities to overcome finance constraints. For these firms, the wedge in low sentiment periods is 850 basis points. This is reduced to zero in high sentiment periods. This corresponds to the case for firms with good investment opportunities illustrated in Figure 2.

\footnotetext{
${ }^{21}$ Erickson and Whited (2000) provide evidence of an important measurement error problem in Tobin's q and cite stock market inefficiencies as one of the possible sources of measurement error.
} 
The same pattern applies to other characteristics that are likely to be associated with finance constraints. For example, $\mu_{t}$ is large, positive, precisely estimated, and highly significant during episodes of low sentiment for non-dividend paying firms with good investment opportunities. During episodes of high sentiment, the external finance premium shrinks by more than $80 \%$. For young firms with good investment opportunities, $\mu_{t}$ is again large, positive, and highly statistically significant during episodes of low sentiment. When sentiment is high, $\mu_{t}$ is dramatically lower and statistically insignificant.

Adjusting for misvaluation in Tobin's q has a qualitative effect on our interpretation of the importance of good and poor investment opportunities in episodes of low sentiment. As we have just discussed, once we adjust for misvaluation, there is strong evidence that finance constraints are important when sentiment is low for small, non-dividend paying, and high volatility firms with good investment opportunities. For the same types of firms, once we control for misvaluation, there is a clear difference between firms with good and poor investment opportunities when sentiment is low. There is no significant evidence of finance constraints for firms with poor investment opportunities. For example, $\mu_{t}$ is essentially 0 for small firms with poor investment opportunities when sentiment is low. This corresponds to the case of firms with poor investment opportunities illustrated in Figure 1. Similarly, $\mu_{t}$ is insignificantly different from 0 for non-dividend paying and high volatility firms with poor investment opportunities when sentiment is low. These key results -1) evidence of a significant external finance premium when sentiment is low for sentiment-sensitive firms with good investment opportunities; and 2) no evidence of a significant external finance premium for sentiment-sensitive firms with poor investment opportunities -- generalize to most of the categories of sentiment-sensitive firms.

The results for unprofitable firms are an exception. There is no particular reason to expect unprofitable firms to be finance constrained, and the estimates in Table 5 provide no evidence of a significant external finance premium for unprofitable firms when sentiment is low, even after controlling for investment opportunities.

When sentiment is high, the estimates show that small firms with poor investment opportunities overinvest. The high sentiment discount is 690 basis points and highly statistically significant. Estimates of $\mu_{t}$ when sentiment is high are also substantial, negative, and statistically significant for non-dividend paying firms with poor investment opportunities, high 
volatility firms with poor investment opportunities, and unprofitable firms with poor investment opportunities. In fact, the estimate of the high sentiment discount is statistically significant for every category of sentiment-sensitive firms, as shown in Table 5.

Another way to avoid the problems that can arise with Tobin's q due to misvaluation is to use a completely different measure of investment opportunities. In Table 6, we measure investment opportunities using demand shocks. ${ }^{22}$ The results are qualitatively similar to those based on Tobin's q adjusted for misvaluation. When sentiment is low, $\mu_{t}$ is a large, positive, and highly significant for most categories of sentiment-sensitive firms with good investment opportunities. High sentiment fully relaxes finance constraints for these firms (in the sense that $\mu_{t}$ is insignificantly different from zero for these firms when sentiment is high). For sentimentsensitive firms with poor investment opportunities, $\mu_{t}$ is insignificantly different from zero when sentiment is low. When sentiment is high, $\mu_{t}$ is negative, large, and highly significant for these firms.

Estimates of the external finance premium are uniformly larger when we use demand shocks to measure investment opportunities than when we use Tobin's q adjusted for misvaluation. Estimates of the high sentiment discount are also uniformly larger when we use demand shocks.

\section{External Finance}

The analysis in Section 2 suggests that external finance will be higher when sentiment is high. As illustrated in Figures 1 and 2, this happens for two reasons. First, a shift from low sentiment to high sentiment relaxes finance constraints. In the example illustrated in the figures, external finance rises from 0 to $I_{G}^{*}-F^{I}$. Second, a shift from low to high sentiment may induce firms with relatively poor investment opportunities to use external finance, if the shift is large enough to make external finance cheaper than internal finance.

Table 7 presents some evidence on external finance. External finance (relative to assets) is about $40 \%$ higher when sentiment is high, as shown in Panel C. The increase is especially big for external equity finance, which is about $50 \%$ greater when sentiment is high.

\footnotetext{
${ }^{22}$ We define demand shocks using real sales growth over the previous three years. Observations with demand shocks above the median for the full sample are classified as having good investment opportunities.
} 
The extent to which firms are sensitive to sentiment (as measured by the characteristics identified by Baker and Wurgler (2006) and that are used in Table 2) makes a substantial difference in how much external finance changes when sentiment shifts. The percentage increase in external finance for sentiment-sensitive firms is more than nine times as large as the increase for firms that are not sensitive to sentiment.

Firms with good investment opportunities use more external finance than firms with poor investment opportunities, whether sentiment is high or low, as shown in Panels A and B. This is hardly surprising and consistent with the analysis in Section 2. Firms with good investment opportunities will have high demand for capital (as illustrated by the $D_{G}$ curves to the right of the $D_{P}$ curves) and are therefore likely to require more external finance to carry out their positive NPV projects. For sentiment-sensitive firms with good investment opportunities, a shift from low to high sentiment seems to particularly help them to obtain external equity financing, which rises by more than five times as much as their debt financing.

The analysis in Section 2 makes no prediction about which effect -- the relaxation of the external finance premium or the increase in the high sentiment discount -- will lead to a bigger burst in external finance when sentiment shifts from low to high. The data provide an interesting answer. The estimates of $\mu$ in earlier tables show a substantial high sentiment discount for firms that are sensitive to sentiment and have poor investment opportunities. These firms experience an explosion of external finance when sentiment shifts from low to high -- an increase of more than $100 \% .^{23}$

\section{Distortions to the Capital Stock}

The estimates in Tables 5 and 6 show that low sentiment can cause finance constraints to bind. According to the estimates, high sentiment can sometimes fully overcome the distortion to investment that arises from asymmetric information. We can use the estimates of $\mu_{t}$ in the tables to calculate the effect of a shift from high to low sentiment on the steady-state capital stock

\footnotetext{
${ }^{23}$ The increase in equity finance is substantial (almost 50\%), but the increase in debt finance is even larger in percentage terms -- from a negligible amount when sentiment is low to almost half of external finance when sentiment is high. This suggests an interesting question for future research: Do banks, bond markets, and other lenders relax their credit standards when sentiment is high (and lend to dodgy borrowers, as seems to have happened in the run-up to the recent credit crisis in the US)?
} 
(under the simplifying assumption that an episode of low sentiment lasts long enough so that the capital stock converges to its steady-state value). The user cost of capital is

$$
R_{t}=\left(r_{t}+\mu_{t}+\delta\right)\left(\frac{1-z_{t}-u_{t}}{1-\tau_{t}}\right) \frac{p_{t}^{I}}{p_{t}^{Y}}
$$

where $\mathrm{z}$ is the ITC rate, $\mathrm{u}$ is the present value of depreciation allowances, $\tau$ is the corporate tax rate, $p^{I}$ is the price of investment goods, and $p^{Y}$ is the price of output. The percentage change in steady-state capital stock is equal to the percentage change in user cost for a change in $\mu_{t}$

$$
\frac{\partial \ln U C}{\partial \mu}=\frac{1}{r+\mu+\delta}
$$

times the user cost elasticity. If we evaluate equation (20) for the change from low to high sentiment, the percentage change in user cost will therefore be

$$
\frac{\mu^{L S}-\mu^{H S}}{r+\mu^{H S}+\delta}
$$

where HS and LS denote high and low sentiment, respectively. For small firms with good investment opportunities, the estimates in Table 5 (combined with the sample means of $\mathrm{r}$ and $\delta$ ) imply an increase in user cost of $45.5 \%$. Using the Caballero (1994) user cost elasticity estimate of approximately -0.9 , this implies that a shift from high to low sentiment decreases the steadystate capital stock by about $41 \%$ for small firms with good investment opportunities.

We can use the same approach to calculate the distortion in the capital stock that arises from the high sentiment discount $\eta_{t}$. When sentiment is low, there is virtually no distortion to the discount rate for small firms with poor investment opportunities (i.e., $\mu_{t}=0.006$ ). When sentiment is high, the high sentiment discount for small firms with poor investment opportunities is 690 basis points. Using the counterpart to equation (21) for a shift from low to high sentiment, the percentage decrease in user cost is about 36.4\%. Using the same Caballero (1994) estimate of user cost elasticity, this implies that high sentiment distorts the steady-state capital stock upwards by about $33 \%$ for small firms with poor investment opportunities. 


\section{Low Sentiment}

"The fear is that the financial markets have entered a negative spiral, the obverse of the kind of euphoria that drove dotcom stocks to absurd valuations in 1999 and early 2000." [The Economist, March 15, 2008, p. 87.]

In 2008, there was some reason to think that the US economy had shifted from high sentiment to low sentiment, as suggested by the quote above from The Economist. What is the macroeconomic effect of low sentiment?

In earlier tables, we report estimates of $\mu$ for specific types of firms, such as small firms, that are more likely to be sensitive to sentiment. This is useful in testing the hypothesis suggested by theoretical models of the effects of sentiment. ${ }^{24}$ Here, our focus is somewhat different. We want to understand the implications of low sentiment for the economy as a whole. As a first step, Table 8 presents estimates of $\mu$ during episodes of low sentiment for firms that are sensitive to sentiment. We define firms as sensitive to sentiment if they have any of the characteristics considered in Table 2; i.e., if they are small, non-dividend paying, high volatility, young, or unprofitable. The estimate of $\mu$, is 810 basis points, with a standard of error of 110 basis points. $^{25}$

How important are firms that are sensitive to sentiment? Table 9 provides evidence based on three different variables. Measured by market capitalization, sentiment-sensitive firms account for slightly more than $49 \%$ of the economy. Sentiment-sensitive firms account for $56 \%$ of investment expenditure and $64 \%$ of the capital stock. By any reasonable measure, sentimentsensitive firms appear to be economically important.

Table 9 also shows the fluctuations in key variables for sentiment-sensitive firms. For example, the market capitalization of sentiment-sensitive firms is about $52 \%$ of total market capitalization in high sentiment years but only about $46 \%$ in low sentiment years. The same pattern is evident in investment. In low sentiment periods, sentiment-sensitive firms shrink relative to the economy as a whole.

\footnotetext{
${ }^{24}$ Several of these models are discussed in Section 2. See also the conclusion of the paper.

${ }^{25}$ The null hypothesis that $\mu$ is the same for sentiment-sensitive and sentiment-insensitive observations is strongly rejected. The Wald test statistic is 22.8 . (p-value: 0.000 ). The point estimate of $\mu$ is small and insignificantly different from 0 for sentiment-insensitive observations.
} 
In view of the quantitative importance of sentiment-sensitive firms, it would not be surprising if $\mu$ were positive for the economy as a whole during periods of low sentiment. Table 10 confirms this. For the economy as a whole, $\mu$ is about 600 basis points during an episode of low sentiment.

\section{Conclusion}

A variety of theoretical work has suggested an interaction between sentiment and other financial market imperfections. Caballero, Farhi, and Hammour (2006) develop an aggregate model of the economy and consider the possibility that speculative episodes may be associated with the relaxation of finance constraints. Farhi and Tirole (2008) model the link between liquidity and investment in an overlapping generations model. They show that shifts in sentiment can have amplified effects on investment through liquidity dry-ups. Jermann and Quadrini (2007) model circumstances in which asset prices that are high (due to optimism) lead to a relaxation of finance constraints and thereby increase productivity. Stein (1996) provides a model of optimal investment and financing in an environment where sentiment can distort the firm's share price.

In order to assess the role of sentiment, we focus on two cross-sectional variables. The first is the extent to which firms tend to be sensitive to sentiment. Baker and Wurgler (2006) identify two relevant criteria. First, the stock prices of firms will be more sensitive to sentiment when it is difficult to form expectations of future cash flows. Second, firms will be more sensitive to sentiment when it is difficult to arbitrage away deviations of their stock price from the expected present value of future cash flows. (Limits to arbitrage might arise due to short sales constraints or the costs and risks of arbitrage strategies.) Based on these two criteria -1) difficulty of valuation and 2) limits to arbitrage -- Baker and Wurgler (2006) identify a number of categories of firms that will be sensitive to sentiment - including small, non-dividend paying, high volatility, young, and unprofitable firms.

In the Stein (1996) model, investor sentiment can affect a firm's investment decisions if the firm's manager has short horizons or if the firm is finance constrained. ${ }^{26}$ With this motivation, we consider a second cross-sectional variable. Economic theory suggests that, other

\footnotetext{
${ }^{26}$ In the Polk and Sapienza (2008) model, firms may overinvest in order to cater to an investor preference in the stock market.
} 
things equal, firms with good investment opportunities are more likely to encounter finance constraints. The intuition for this is simple: Comparing otherwise similar firms, the firm with better investment opportunities is more likely to exhaust internal finance and therefore require external finance. This intuition is illustrated in Figures 1 and 2.

The results are striking. When sentiment is high, hurdle rates are distorted downward for sentiment-sensitive firms with relatively poor investment opportunities. Downward distortion of hurdle rates when sentiment is high implies the kind of overinvestment many people believe occurred during the tech bubble in the late 1990s. The data used in the paper cover fluctuations in sentiment over a much longer period 1980-2004, suggesting that the effects of high sentiment are not restricted to the late 1990s. Interestingly, there is little evidence that hurdle rates are distorted for firms with relatively good investment opportunities when sentiment is high (even for the firms that are likely to be the most sensitive to sentiment).

In contrast, when sentiment is low, the hurdle rate is distorted upward for firms that have good investment opportunities and are sensitive to sentiment. (This is consistent with Jeremy Stein's model of the effect of sentiment on hurdle rates.) Upper distortion of the hurdle rate leads to underinvestment when sentiment is low. There is little evidence that hurdle rates are distorted for firms with relatively poor investment opportunities when sentiment is low (even for sentiment-sensitive firms).

Thus, there are two effects of a shift from high to low sentiment. First, hurdle rates are distorted upward for firms with relatively good investment opportunities. Second, the downward distortion in hurdle rates for firms with relatively poor investment opportunities is eliminated. Both effects increase hurdle rates. A shift from high to low sentiment therefore increases the hurdle rates for firms, regardless of whether they have relatively good or poor investment opportunities. For the firms that are most likely to be sensitive to sentiment, statistical tests strongly reject the null hypothesis that the discount rate is the same in high and low sentiment periods. (In most cases, the p-value is less than 0.001.)

How large is the effect of a shift in sentiment on the economy as a whole? To answer this question, we estimate the effect for all firms (not just those that are sensitive to sentiment). For the economy as a whole, an episode of low sentiment raises the hurdle rate by 590 basis points. The estimated effect is precisely estimated and statistically significant. 
In addition to investment, we also examine financing. External finance (relative to assets) is about $40 \%$ higher when sentiment is high. The boom in external finance is particularly pronounced in external equity finance. When we compare cross-sectionally, the percentage increase in external finance is more than nine times as large for sentiment-sensitive firms as for firms that have been identified as insensitive to sentiment.

The estimates allow us to quantify both the beneficial effect of high sentiment on the steady-state capital stock (relaxing finance constraints) and the distortionary effect (inducing overinvestment by firms with poor investment opportunities). Based on the Caballero (1994) estimate of user cost elasticity, a shift from high sentiment to low sentiment tightens finance constraints for small firms with good investment opportunities and thereby decreases their steady-state capital stock by $41 \%$. A similar calculation shows that the distortionary effect of high sentiment raises the steady-state capital stock $33 \%$ above the first-best level for small firms with poor investment opportunities. 


\section{References}

Akerlof, George A., "The Market for "Lemons": Quality Uncertainty and the Market Mechanism," Quarterly Journal of Economics 84 (August 1970), 488-500.

Amihud, Yakov, and Mendelson, Haim, “Asset pricing and the bid-ask spread," Journal of Financial Economics 17 (1986) 223-249.

Andrews, Donald W. K. and Lu, Biao, "Consistent model and moment selection procedures for GMM estimation with application to dynamic panel data models," Journal of Econometrics 101 (March 2001), 123-164.

Baker, Malcolm, Ruback, Richard S., and Wurgler, Jeffrey, "Behavioral Corporate Finance: A Survey," in Espen Eckbo (ed.), Handbook of Corporate Finance: Empirical Corporate Finance (Elsevier, 2004), 145-185.

Baker, Malcolm, Stein, Jeremy C., and Wurgler, Jeffrey, "When Does The Market Matter? Stock Prices and the Investment of Equity-Dependent Firms," Quarterly Journal of Economics 118 (August 2003), 969-1005.

Baker, Malcolm, and Wurgler, Jeffrey, "Investor Sentiment and the Cross-Section of Stock Returns," Journal of Finance 61 (August 2006), 1645-1680.

Barberis, Nicholas, Shleifer, Andrei, and Vishny, Robert, "A Model of Investor Sentiment," Journal of Financial Economics 49 (1998), 307-343.

Barro, Robert J., “The stock market and investment,” Review of Financial Studies 3 (1990), 115132.

Bernanke, Ben, and Gertler, Mark, "Agency Costs, Net Worth, and Business Fluctuations," American Economic Review 79 (March 1989), 14-31.

Bernanke, Ben, Gertler, Mark, and Gilchrist, Simon, "The Financial Accelerator in a Quantitative Business Cycle Framework," J. B. Taylor and M. Woodford (eds.) Handbook of Macroeconomics (Elsevier, 1999) 1341-1393.

Bertola, Guiseppe and Caballero, Ricardo J, "Irreversibility and Aggregate Investment," Review of Economic Studies 61 (April 1994), 223-46.

Blanchard, Olivier J., Rhee, Changyong, and Summers, Lawrence H., "The Stock Market, Profit and Investment," Quarterly Journal of Economics 108 (February 1993), 115-136.

Blanchard, Olivier J., and Watson, Mark, "Bubbles, Rational Expectations and Financial Markets," in Paul Wachtel (ed.), Crises in the Economic and Financial Structure (Lexington, MA: Lexington Books, 1982), 295-315. 
Bond, Stephen R., and Cummins, Jason G., "Noisy Share Prices and the Q Model of Investment," Oxford University (2001).

Brunnermeier, Markus K., and Pedersen, Lasse Heje, "Predatory Trading” The Journal of Finance 60 (August 2005), 1825-1863.

Caballero, Ricardo J., "Small Sample Bias and Adjustment Costs," The Review of Economics and Statistics 76 (February 1994), 52-58.

Caballero, Ricardo J., Farhi, Emmanuel, and Hammour, Mohamad L., "Speculative Growth: Hints from the U.S. Economy," American Economic Review 96 (September 2006), 11591192.

Chirinko, Robert S., Fazzari, Steven M., and Meyer, Andrew P., "How Responsive Is Business Capital Formation To Its User Cost?: An Exploration With Micro Data," Journal of Public Economics 74 (October 1999), 53-80.

Chirinko, Robert S., and Schaller, Huntley, "Bubbles, Fundamentals, and Investment: A Multiple Equation Testing Strategy," Journal of Monetary Economics 38 (August 1996), 47-76.

Chirinko, Robert S., and Schaller, Huntley. "Business Fixed Investment and 'Bubbles': The Japanese Case," American Economic Review 91 (June 2001), 663-680.

Chirinko, Robert S., and Schaller, Huntley, "A revealed preference approach to understanding corporate governance problems: Evidence from Canada," Journal of Financial Economics 74 (April 2004), 181-206.

D'Avolio, Gene, "The market for borrowing stock," Journal of Financial Economics 66 (November-December 2002), 271-306.

Duffie, Darrell, Gârleanu, Nicolae, and Pedersen, Lasse Heje, "Securities lending, shorting, and pricing," Journal of Financial Economics 66 (November-December 2002), 307-339.

Erickson, Timothy, and Whited. Toni M., "Measurement Error and the Relationship between Investment and q," Journal of Political Economy 108 (October 2000), 1027-1057.

Farhi, Emmanuel, and Tirole, Jean, "Competing Liquidities: Corporate Securities, Real Bonds and Bubbles,” NBER Working Paper Series 13955, (April 2008).

Fazzari, Steven M., Hubbard, R. Glenn, and Petersen, Bruce C., "Financing Constraints and Corporate Investment," Brookings Papers on Economic Activity (1988:1), 141-195.

Fisher, Jonas D.M., "The Dynamic Effects of Neutral and Investment-Specific Technology Shocks," Journal of Political Economy 114 (June 2006), 413-451. 
Galeotti, Marzio, and Schiantarelli, Fabio, "Stock Market Volatility and Investment: Do Only Fundamentals Matter?," Economica 61 (1994), 147-165.

Geczy, Christopher C., Musto, David K. and Reed, Adam V., "Stocks are special too: an analysis of the equity lending market," Journal of Financial Economics 66 (November-December 2002), 241-269.

Gilchrist, Simon, Himmelberg, Charles, Huberman, Gur, "Do Stock Price Bubbles Influence Corporate Investment?" Journal of Monetary Economics 52 (May 2005), 805-827.

Hubbard, R. Glenn, "Capital-Market Imperfections and Investment," Journal of Economic Literature 36 (March 1998), 193-225.

Jermann, Urban J., and Quadrini, Vincenzo, "Stock market boom and the productivity gains of the 1990s," Journal of Monetary Economics 54 (March 2007), 413-432.

Jones, Charles M., and Lamont, Owen A. "Short-Sale Constraints and Stock Returns," Journal of Financial Economics 66 (November-December 2002), 207-239.

Kiyotaki, Nobuhiro, and Moore, John, "Credit Cycles," The Journal of Political Economy 105 (April 1997), 211-248.

Lamont, Owen A., "Investment plans and stock returns," Journal of Finance 55 (2000), 27192745.

Lamont, Owen A., and Thaler, Richard H., "Can the market add and subtract? Mispricing in tech stock carve-outs," Journal of Political Economy 111 (April 2003), 227-268.

Lorenzoni, Guido, "A Theory of Demand Shocks," conditionally accepted at the American Economic Review.

Malmendier, Ulrike, and Tate, Geoffrey, "CEO Overconfidence and Corporate Investment," The Journal of Finance 60 (December 2005), 2661-2700.

Markowitz, Harry, Portfolio Selection: Efficient Diversification of Investments. New York: Wiley (1959).

Mitchell, Mark L., Pulvino, Todd, and Stafford, Erik, "Limited arbitrage and equity markets," Journal of Finance 57 (2002), 551-584.

Morck, Randall, Shleifer, Andrei, and Vishny, Robert W., "The Stock Market and Investment: Is the Market a Sideshow?," Brookings Papers on Economic Activity (1990:2), 157-202. 
Myers, Stewart C., and Majluf, Nicholas S., "Corporate financing and investment decisions when firms have information that investors do not have," Journal of Financial Economics (1984), 187-221.

Olivier, Jacques, "Growth-Enhancing Bubbles," International Economic Review 41 (February 2000), 133-151.

Panageas, Stavros, "Speculation, overpricing, and investment: Theory and empirical evidence," MIT working paper (2003).

Pechman, Joseph A., Federal Tax Policy, Fifth Edition (Washington: Brookings Institution, 1987).

Polk, Christopher, and Sapienza, Paola, "The Stock Market and Corporate Investment: a Test of Catering Theory," Review of Financial Studies (2008).

Scheinkman, Jose A., and Xiong, Wei, "Overconfidence and Speculative Bubbles," Journal of Political Economy 111 (December 2003), 1183-1219.

Schiantarelli, Fabio, "Financial Constraints and Investment: A Critical Review of Methodological Issues and International Evidence," in Joe Peek and Eric S. Rosengren (eds.), Is Bank Lending Important For The Transmission Of Monetary Policy? (Boston: Federal Reserve Bank Of Boston, 1995), 177-214.

Shleifer, Andrei, and Vishny, Robert W., "The limits of arbitrage," Journal of Finance 52 (1997), 35-55.

Stein, J., "Rational capital budgeting in an irrational world," Journal of Business 69 (1996), 42955.

Stein, Jeremy C., "Agency, Information and Corporate Investment," in G.M. Constantinides, M. Harris, and R. Stulz (eds.), Handbook of the Economics of Finance (Elsevier, 2003), 111163.

Stiglitz, Joseph E., and Weiss, Andrew, "Credit Rationing in Markets with Imperfect Information," The American Economic Review 71 (1981), 393-410.

Whited, Toni M., "Debt, Liquidity Constraints, and Corporate Investment: Evidence from Panel Data," Journal of Finance 47 (September 1992), 1425-1460.

Wurgler, Jeffrey, and Zhuravskaya, Katia, "Does arbitrage flatten demand curves for stocks?," Journal of Business 75 (2002), 583-608. 


\section{Data Appendix \\ Not For Publication}

\section{Sentiment Index}

The sentiment index is the Baker-Wurgler series SENTIMENT ${ }^{\perp}$ from the Journal of Finance website.

\section{Capital Stock and Investment}

For the first observation for firm $f$, the capital stock is based on the net plant (NPLANT), the nominal book value of net property, plant, and equipment (CompuStat item 8). To convert this to real terms, we divide by the sector-specific price index for investment $\left(p^{I}\right)$. Since book value is not adjusted for changes in the value of capital goods purchased in the past, we adjust the initial capital stock using a sector-specific adjustment factor $(A F)$ :

$$
K_{f, t_{0}^{f}}=\frac{N P L A N T_{f, t_{0}^{f}}}{p_{s, t_{0}^{f}}^{I}} A F_{s}
$$

where $\mathrm{s}$ is a sector index (for firm $f^{\prime} \mathrm{s}$ sector) and $t_{0}^{f}$ is the year of the first observation for firm $f$.

Failure to adjust book value affects the initial value of the capital stock but has a geometrically decreasing impact on the measured capital stock over time. After 15 years, the initial value effect is negligible. We use this fact to construct the adjustment factor for the initial value of the capital stock. For sector $s, A F$ is (the ratio of current cost net stock of private fixed assets by industry to the historical-cost net stock of private fixed assets by industry) times (the ratio of the mean unadjusted capital stock for firms of age 15 or greater to the mean of what the unadjusted capital stock would have been measured as, if $t$ equaled $t_{0}^{f}$ (i.e., if the current year were the firm's first year in the sample)). In effect, AF is the ratio of the true capital stock to the unadjusted initial value.

For subsequent observations, a standard perpetual inventory method is used to construct the capital stock,

$$
K_{f, t+1}=\left(1-\delta_{s, t}\right) K_{f, t}+\frac{K C H G_{f, t+1}}{p_{s, t+1}^{I}}
$$

where $\delta$ is the depreciation rate and $K C H G$ is gross additions to the firm's capital stock. The firm reports the additions in nominal terms, so we divide by $p^{I}$ to convert to real terms.

In the standard case, $K C H G$ is gross investment (I), which is capital expenditures in the firm's financial statements (CompuStat item 128). CompuStat does not always have reliable data for the additions to the capital stock associated with large acquisitions. We use a modified version of the algorithm of Chirinko, Fazzari, and Meyer (1999) to adjust $K C H G$ for acquisitions and divestitures. In the case of a substantial acquisition, we can use accounting identities to derive a more accurate measure of the additions to the capital stock: 
$\operatorname{DGPLANT}_{f, t}=I_{f, t}+\operatorname{ACQUIS}_{f, t}-\operatorname{RETIRE}_{f, t}$

where DGPLANT $T_{t}$ is the change in GPLANT from the end of year $t-1$ to the end of year $t$ and GPLANT $T_{t}$ is gross property, plant, and equipment (CompuStat item 7), ACQUIS is acquisitions, and RETIRE is retirements of capital stock (CompuStat item 184). (When data on RETIRE is missing, we assume that the reason is that firms do not report any retirements in their financial statements, and we therefore assign a value of 0 to RETIRE for these observations.) We use the following screen to identify cases where there has been a substantial acquisition. If

$\frac{\operatorname{DGPLANT}_{f, t}-I_{f, t}}{\operatorname{GPLANT}_{f, t-1}}>0.1$

then we calculate the gross change in the capital stock as

$K C H G_{t}=D G P L A N T_{t}+R E T I R E_{t}$

We also account for substantial divestitures, using the following screen. If

$\frac{\operatorname{DGPLANT}_{f, t}+\operatorname{RETIRE}_{f, t}}{\operatorname{GPLANT}_{f, t-1}}<-0.1$

we calculate the change in the capital stock as

$K C H G_{f, t}=D N P L A N T_{f, t}+\delta K_{f, t-1} p_{s, t}^{I}$

where DNPLANT is the change in NPLANT (as defined above). ${ }^{27}$ Because NPLANT in the firm's financial statements will deduct depreciation (as well as accounting for the divestiture), depreciation must be added to $K C H G$ to avoid deducting depreciation twice.

If $G P L A N T_{f, t-1}$ is missing (or equal to zero) or $D G P L A N T_{f, t}$ is missing, it is not feasible to use these screens, and we set $K C H G$ equal to $I$.

In some cases, there is a data gap for a particular firm. In this case, we treat the first new observation for that firm in the same way as we would if it were the initial observation. This avoids any potential sample selection bias that would result from dropping firms with gaps in their data.

\footnotetext{
${ }^{27}$ To see this result, start with the perpetual inventory equation, $K_{t}=I_{t}+(1-\delta) K_{t-1}$ $K_{t}-K_{t-1}+\delta K_{t-1}=I_{t}$

Now, put the previous equation in nominal terms.

$\left[K_{t}-K_{t-1}\right] p_{t}^{I}+\delta K_{t-1} p_{t}^{I}=I_{t} p_{t}^{I}$

$D N P L A N T_{t}+\delta K_{t-1} p_{t}^{I}=I_{t} p_{t}^{I}=K C H G_{t}$
} 
We construct sector-specific, time-varying depreciation rates using data from the BEA. Specifically,

$\delta_{s, t}=\frac{D \$_{s, 1996} D Q U A N T_{s, t}}{K \$_{s, 1996} K Q U A N T_{s, t}}$

where $D \$$ is current-cost depreciation of private fixed assets by sector (BEA, Table 3.4ES), $D Q U A N T$ is the chain-type quantity index of depreciation of private fixed assets by sector (BEA, Table 3.5ES), $K \$$ is the current cost net stock of private fixed assets by sector (as defined above), and KQUANT is the chain-type quantity index of the net stock of private fixed assets by sector (BEA, Table 3.2ES).

We construct the sector-specific price index for investment using BEA data:

$p_{s, t}^{I}=\frac{100\left(I \$_{s, t} / I \$_{s, 1996}\right)}{I Q U A N T_{s, t}}$

where $I \$$ is historical-cost investment in private fixed assets by sector (BEA, Table 3.7ES) and IQUANT is the chain-type quantity index of investment in private fixed assets by sector (BEA, Table 3.8ES).

The variables obtained from the BEA for constructing depreciation rates and price indices for investment are calculated for 2002, 2003, and 2004 by extending the corresponding 1950 to 2001 data series, which are reported with a somewhat different classification scheme. (The data for 1950 to 2001 are on a SIC basis, while the data for 2002 to 2004 are on a NAICS basis.) This extension uses BEA data for 2002 through 2004 to calculate the percentage change in a given variable between two years and then multiplies by the previous observation in the existing series to get the new value. For example, for 2002 , the variable $K \$$ is calculated for each industry as:

$$
K \$_{s, 2002}=K \$_{s, 2001}\left(\frac{K \$_{s, 2002}^{M R}}{K \$_{s, 2001}^{M R}}\right)
$$

where the superscript $M R$ denotes the more recent version of the variable. The validity of this procedure was evaluated by comparing values estimated by the procedure represented in equation (B5) for 2001 with data on the prior classification for 2001.

\section{Tax-Adjusted Relative Price of Investment Goods}

We define the tax-adjusted relative price of investment goods as follows,

$$
p_{s, t}^{I}=\left(\frac{1-z_{t}-u_{t}}{1-\tau_{t}}\right) \frac{p_{s, t}^{I @}}{p_{s, t}^{Y}}
$$


where $z$ is the present value of depreciation allowances, $u$ is the investment tax credit rate, $\tau$ is the corporate tax rate, $p^{I @}$ is the price of investment goods, and $p^{Y}$ is the price of output. Where variables are available at a monthly or quarterly frequency, we take the average for the calendar year. The corporate tax rate is the U.S. federal tax rate on corporate income. The present value of depreciation allowances - for non-residential equipment and structures, respectively - were provided by Dale Jorgenson. (The data provided by Dale Jorgenson end in 2001; for 2002-04, we use 2001 values.) To calculate $\mathrm{z}$, we took the weighted sum of Jorgenson's z's for equipment and structures, where the weights are the share of equipment investment and the share of structures investment (for a given year) in nominal gross private non-residential investment in fixed assets from the Bureau of Economic Analysis (from table 1IHI, where equipment investment is referred to as equipment and software). Because the investment tax credit applies only to equipment, $u=0$ for structures, we multiply the statutory ITC rate for each year by the ratio of equipment investment to the sum of structures and equipment investment for that year. The corporate tax rates were provided directly by the Treasury Department, and investment tax credit rates are drawn from Pechman (1987, p.160-161). For the years 1980 to 2001, the sectorspecific price index for output, $p^{Y}$, is the implicit price deflator for Gross Domestic Product by industry produced by the BEA, normalized to 1 in 1996. For 2002 through 2004, the sectorspecific price index is recursively extended forward by:

$$
p_{s, t+1}^{Y}=p_{s, t}^{Y}\left(\frac{p_{t+1}^{A}}{p_{t}^{A}}\right)
$$

where $p^{A}$ is the aggregate non-farm business price index for gross value added (BEA Table 1.3.4).

\section{The Real Risk-Adjusted Market Discount Rate}

The real, risk-adjusted market discount rate is defined as follows,

$$
r_{f, t}=\left(\left(1+r_{f, t}^{N O M}\right) /\left(1+\pi_{t}^{e}\right)\right)-1.0
$$

The equity risk premium is calculated using the Fama-French three-factor model. The components of $\mathrm{r}_{\mathrm{f}, \mathrm{t}}$ are defined and constructed as follows,

$$
\begin{aligned}
& r_{f, t}^{N O M} \quad=\quad \text { Nominal, short-term, risk-adjusted cost of capital } \\
& =\lambda_{\mathrm{s}}\left(1-\tau_{\mathrm{t}}\right) r_{t}^{N O M, D E B T}+\left(1-\lambda_{\mathrm{s}}\right) r_{s, t}^{N O M, E Q U I T Y} \text {. } \\
& r_{t}^{\text {NOM }, D E B T}=\quad \text { Nominal corporate bond rate (Moody's Seasoned Baa } \\
& \text { Corporate Bond Yield) } \\
& r_{s, t}^{\text {NOM }, \text { EQUITY }}=\text { Nominal, short-term, risk-adjusted cost of equity capital for } \\
& \text { firms in sector s. }
\end{aligned}
$$




\begin{tabular}{|c|c|c|}
\hline$r_{t}^{N O M, F}$ & $=$ & $\begin{array}{l}\text { Nominal, one-year, risk-free rate (One-Year Treasury Constant Maturity } \\
\text { Rate) }\end{array}$ \\
\hline$\pi_{s, t}^{e}$ & $=$ & $\begin{array}{l}\text { Sector-specific capital goods price inflation rate from } t \text { to } t+1 \text {. Sector- } \\
\text { specific data was not yet available for } 2005 \text { at the time of data } \\
\text { construction, so } \pi_{s, t}^{e} \text { for } 2003 \text { was also used for } 2004 \text {. }\end{array}$ \\
\hline$\sigma_{\mathrm{s}}$ & $=$ & Equity risk premium. \\
\hline$\tau_{\mathrm{t}}$ & $=$ & Marginal rate of corporate income taxation. \\
\hline$\lambda_{\mathrm{s}}$ & $=$ & $\begin{array}{l}\text { Sector-specific leverage ratio calculated as the mean of book debt for the } \\
\text { sector divided by the mean of (book debt }+ \text { book equity) for the sector. }\end{array}$ \\
\hline
\end{tabular}

Under the Fama-French three-factor model,

$\sigma_{s}=\beta_{s}^{E M R} \mu^{E M R}+\beta_{s}^{S M B} \mu^{S M B}+\beta_{s}^{H M L} \mu^{H M L}$

where $\mu$ denotes a mathematical expectation (the sample mean, in an empirical context). We calculate the Fama-French three-factor model betas by estimating the regression

$$
E F R_{f, t}=\alpha_{s}+\beta_{s}^{E M R} E M R_{t}+\beta_{s}^{S M B} S M B_{t}+\beta_{s}^{H M L} H M L_{t}+\varepsilon_{f, t}
$$

over all firms in each sector $s$, where $E F R_{f, t}$ is the excess firm return (the monthly return of firm $f$ minus the risk free rate), $E M R_{t}$ is the excess market return (value-weighted market return minus the risk free rate), $S M B_{t}$ is the size risk factor (average return on three small portfolios minus the average return on three big portfolios), and $H M L_{t}$ is the book-to-market risk factor (average return on two value portfolios minus the average return on two growth portfolios).

The risk free rate is the one-month treasury bill rate. The three factors and the risk free rate are taken from Kenneth French's website. ${ }^{28}$ The monthly firm returns are taken from the CRSP database.

\section{Firm Characteristics}

We define "small" firms to be those observations with market equity (ME) below the median over all firm-year observations, where ME is defined to be equal to the number of common shares outstanding (Compustat Item 25) multiplied by the share price at the end of firm's fiscal year (Compustat Item 199).

\footnotetext{
${ }^{28}$ Available as "Fama/French Factors" at: http://mba.tuck.dartmouth.edu/pages/faculty/ken.french/data_library.html
} 
"Non-dividend-paying" observations are the observations where dividends are less than or equal to zero, where dividends are defined as dividends per share at the ex date (Compustat Item 26).

"High volatility" observations are the observations where the standard deviation of monthly CRSP returns (calculated over a given year for each firm) is above the median (calculated over all firm-year observations).

The "young" characteristic corresponds to observations where the firm is below the median of the age distribution, where the age of the firm is the number of years since it entered the Compustat database.

We define "unprofitable" observations as those where profit is less than or equal to zero, where profit is defined as income before extraordinary items (Compustat Item 18) plus income statement deferred taxes (Compustat Item 50) minus preferred dividends (Compustat Item 19).

"Low earnings" observations are observations where $\mathrm{E} / \mathrm{BE}$ is below the median (calculated over all firm-year observations), where $\mathrm{E}$ is earnings, defined as income before extraordinary items (Compustat Item 18) plus income statement deferred taxes (Compustat Item 50) minus preferred dividends (Compustat Item 19), and BE is book equity, defined as shareholders' equity (Compustat Item 60) plus balance sheet deferred taxes (Compustat Item 35).

"Few tangible assets" observations are observations where PPE/A is below the median (calculated over all firm-year observations), where PPE is total gross property, plant, and equipment (Compustat Item 7), and A denotes assets (Compustat Item 6).

"High and low book-to-market" observations are defined as the top two and bottom two deciles of $\mathrm{BE} / \mathrm{ME}$, where $\mathrm{BE}$ is book equity, defined to be equal to shareholders' equity (Compustat Item 60) plus balance sheet deferred taxes (Compustat Item 35), and ME is market equity as defined above. 
Table 1

Summary Statistics

\begin{tabular}{|l|c|c|c|c|c|}
\hline & $\mathrm{I} / \mathrm{K}$ & $\mathrm{K}$ & $\mathrm{ME}$ & Real Sales & $\begin{array}{c}\text { Real Sales } \\
\text { Growth }\end{array}$ \\
\hline All & 0.073 & 70.097 & 74.130 & 108.210 & 0.066 \\
& $(0.126)$ & $(8798.950)$ & $(1407.860)$ & $(1461.910)$ & $(0.689)$ \\
& {$[0.156]$} & {$[58233.810]$} & {$[10154.880]$} & {$[7065.740]$} & {$[26.824]$} \\
\hline Small & 0.054 & 20.669 & 16.733 & 30.950 & 0.054 \\
& $(0.108)$ & $(4800.010)$ & $(100.585)$ & $(512.054)$ & $(0.921)$ \\
& {$[0.148]$} & {$[42166.810]$} & {$[1302.640]$} & {$[4319.270]$} & {$[29.510]$} \\
\hline Non-Dividend- & 0.074 & 30.327 & 37.297 & 48.078 & 0.084 \\
Paying & $(0.137)$ & $(4383.960)$ & $(480.628)$ & $(621.131)$ & $(0.954)$ \\
& {$[0.169]$} & {$[40765.730]$} & {$[4806.810]$} & {$[4073.110]$} & {$[32.117]$} \\
\hline High Volatility & 0.087 & 30.698 & 45.408 & 56.050 & 0.078 \\
& $(0.147)$ & $(1418.890)$ & $(653.184)$ & $(619.731)$ & $(0.708)$ \\
& {$[0.169]$} & {$[28654.440]$} & {$[5746.400]$} & {$[4023.270]$} & {$[30.119]$} \\
\hline Young & 0.087 & 34.870 & 56.655 & 55.503 & 0.111 \\
& $(0.155)$ & $(4198.130)$ & $(773.780)$ & $(616.408)$ & $(1.096)$ \\
& {$[0.182]$} & {$[55967.730]$} & {$[5822.480]$} & {$[3086.500]$} & {$[30.477]$} \\
\hline Unprofitable & 0.054 & 24.446 & 29.845 & 30.812 & 0.056 \\
& $(0.113)$ & $(7159.130)$ & $(639.368)$ & $(808.472)$ & $(1.439)$ \\
& {$[0.158]$} & {$[54922.960]$} & {$[4199.560]$} & {$[4910.900]$} & {$[41.743]$} \\
\hline Low Earnings & 0.059 & 42.485 & 42.228 & 59.426 & 0.056 \\
& $(0.113)$ & $(8846.340)$ & $(911.338)$ & $(1171.150)$ & $(0.982)$ \\
& {$[0.151]$} & {$[61750.690]$} & {$[9189.540]$} & {$[6489.570]$} & {$[34.541]$} \\
\hline Few Tangible & 0.106 & 20.583 & 57.146 & 56.521 & 0.104 \\
Assets & $(0.168)$ & $(574.448)$ & $(1040.800)$ & $(844.760)$ & $(0.893)$ \\
& {$[0.181]$} & {$[8209.640]$} & {$[8359.140]$} & {$[5766.880]$} & 25.051 \\
\hline High \& Low & 0.054 & 42.389 & 32.927 & 62.063 & 0.034 \\
Book-to-Market & $(0.112)$ & $(8952.610)$ & $(1405.250)$ & $(1083.790)$ & $(0.847)$ \\
& {$[0.156]$} & {$[60083.880]$} & {$[10893.910]$} & {$[6164.750]$} & {$[34.130]$} \\
\hline
\end{tabular}

Each cell contains the median, (mean), and [standard deviation] of the corresponding variable. $\mathrm{I} / \mathrm{K}$ is the investment/capital ratio, ME is market equity, BE is book equity, and GS is sales growth. "High and low" refer to the top and bottom two deciles of the distribution (i.e., the top and bottom $20 \%$ of the BE/ME distribution). 
Table 2

Low Sentiment

Firm Characteristics Associated with Sensitivity to Sentiment

\begin{tabular}{|l|c|c|c|c|c|}
\hline \multirow{2}{*}{} & \multicolumn{5}{|c|}{ Firm Characteristics } \\
\cline { 2 - 6 } & Small & $\begin{array}{c}\text { Non- } \\
\text { Dividend- } \\
\text { Paying }\end{array}$ & $\begin{array}{c}\text { High } \\
\text { Volatility }\end{array}$ & Young & Unprofitable \\
\hline$\mu$ & 0.042 & 0.082 & 0.101 & 0.081 & -0.010 \\
& $(0.019)$ & $(0.012)$ & $(0.022)$ & $(0.013)$ & $(0.049)$ \\
\hline$\zeta$ & 0.906 & 0.898 & 0.905 & 0.897 & 0.907 \\
& $(0.015)$ & $(0.022)$ & $(0.023)$ & $(0.017)$ & $(0.016)$ \\
\hline$\alpha_{0}$ & 0.325 & 1.192 & 1.345 & 0.765 & 0.318 \\
& $(0.554)$ & $(1.057)$ & $(1.191)$ & $(0.682)$ & $(0.500)$ \\
\hline$\alpha_{1}$ & 52.629 & 69.463 & 75.429 & 54.266 & 46.693 \\
& $(18.462)$ & $(28.679)$ & $(32.253)$ & $(16.792)$ & $(16.946)$ \\
\hline & 2.152 & 0.661 & 0.502 & 0.324 & 1.296 \\
& {$[0.142]$} & {$[0.416]$} & {$[0.479]$} & {$[0.569]$} & {$[0.255]$} \\
\hline$G_{I}\left[I_{t}, K_{t-1}\right]$ & 7.177 & 10.236 & 11.161 & 7.830 & 6.397 \\
\hline$G_{I I}\left[I_{t}, K_{t-1}\right]$ & 6.610 & 5.714 & 8.290 & 6.816 & 5.865 \\
\hline $\mathrm{N}$ & 71567 & 71567 & 64048 & 71567 & 71567 \\
\hline
\end{tabular}

The parameter $\mu$ is the discount rate wedge; i.e., the difference between the discount rate used by the firm in making intertemporal decisions and the risk-adjusted interest rate. Standard errors are in parentheses under the parameter estimates. The $\mathbf{J}$ statistic is the Hansen $\mathbf{J}$ statistic for testing overidentifying restrictions (with p-values in brackets). The parameter $\zeta$ captures the combined effects of non-constant returns to scale and imperfect competition. The parameters $\alpha_{0}$ and $\alpha_{1}$ determine marginal adjustment costs. $\mathrm{N}$ is the number of firm/year observations. The estimation method is GMM with the following instruments: a constant, SALES/K, $\mathrm{I} / \mathrm{K}, 1+r+\delta$, $p^{I} / p^{Y}$ (all for the previous period and adjusted for taxes), and an indicator variable $\left(\Gamma_{t-1}\right)$ for low sentiment and the class of observations (listed at the top of the column). $G_{I}\left[I_{t}, K_{t-1}\right]$ is the marginal adjustment cost. $G_{I I}\left[I_{t}, K_{t-1}\right]$ is the curvature of the adjustment cost function; both are evaluated for each observation and the mean is reported in the table. 
Table 3

Tests of the Effect of Sentiment

\begin{tabular}{|l|c|c|c|}
\hline & High sentiment $\mu$ & Low sentiment $\mu$ & $\begin{array}{c}\text { Difference } \\
\text { (Wald) }\end{array}$ \\
\hline Small & -0.029 & 0.035 & -0.063 \\
& $(0.013)$ & $(0.021)$ & $(12.461)$ \\
& & & {$[0.000]$} \\
\hline Non-Dividend- & 0.022 & 0.088 & -0.066 \\
Paying & $(0.010)$ & $(0.012)$ & $(26.240)$ \\
& & & {$[0.000]$} \\
\hline High Volatility & 0.011 & 0.105 & -0.094 \\
& $(0.019)$ & $(0.026)$ & $(15.481)$ \\
& & 0.090 & -0.117 \\
\hline Young & -0.027 & $(0.014)$ & $(26.633)$ \\
& $(0.013)$ & -0.003 & {$[0.000]$} \\
\hline Unprofitable & -0.067 & $(0.046)$ & -0.064 \\
& $(0.037)$ & & {$[3.935)$} \\
& & 0.057 & -0.103 \\
\hline Low Earnings & -0.046 & $(0.032)$ & $(22.089)$ \\
& $(0.027)$ & 0.034 & -0.046 \\
\hline Few Tangible & -0.012 & $(0.014)$ & $(8.754)$ \\
Assets & $(0.011)$ & & {$[0.003]$} \\
\hline High \& Low & -0.050 & $(0.029)$ & -0.116 \\
Book-to-Market & $(0.020)$ & & {$[12.680)$} \\
& & & {$[0.000]$} \\
\hline
\end{tabular}

The parameter $\mu$ is the discount rate wedge; i.e., the difference between the discount rate used by the firm in making intertemporal decisions and the risk-adjusted interest rate. Standard errors are in parentheses under the parameter estimates. The row labeled "Difference" reports the difference between $\mu$ during high and low sentiment episodes. The test statistic for the difference is in parentheses and the p-value is in square brackets. The estimation method is described under Table 2. 
Table 4

Sentiment and Investment Opportunities

Tobin's q

\begin{tabular}{|l|c|c|c|c|}
\hline \multirow{2}{*}{} & \multicolumn{2}{|c|}{ Low sentiment } & \multicolumn{2}{c|}{ High sentiment } \\
\cline { 2 - 5 } & \multicolumn{2}{|c|}{ Investment Opportunities } & \multicolumn{2}{c|}{ Investment Opportunities } \\
\cline { 2 - 5 } & Good & Poor & Good & Poor \\
\hline Small & 0.046 & 0.044 & -0.029 & -0.049 \\
& $(0.031)$ & $(0.025)$ & $(0.024)$ & $(0.014)$ \\
\hline Non-Dividend- & 0.092 & 0.093 & 0.009 & -0.039 \\
Paying & $(0.016)$ & $(0.026)$ & $(0.015)$ & $(0.016)$ \\
\hline High Volatility & 0.085 & 0.149 & 0.001 & -0.068 \\
& $(0.030)$ & $(0.049)$ & $(0.021)$ & $(0.025)$ \\
\hline Young & 0.071 & 0.156 & -0.007 & -0.062 \\
& $(0.019)$ & $(0.039)$ & $(0.019)$ & $(0.023)$ \\
\hline Unprofitable & -0.072 & 0.184 & -0.109 & -0.003 \\
& $(0.072)$ & $(0.061)$ & $(0.050)$ & $(0.035)$ \\
\hline Low Earnings & 0.057 & 0.098 & -0.062 & -0.050 \\
& $(0.041)$ & $(0.033)$ & $(0.033)$ & $(0.020)$ \\
\hline Few Tangible & 0.063 & -0.038 & -0.007 & -0.069 \\
Assets & $(0.015)$ & $(0.036)$ & $(0.014)$ & $(0.025)$ \\
\hline High \& Low & 0.107 & 0.010 & -0.019 & -0.082 \\
Book-to-Market & $(0.037)$ & $(0.038)$ & $(0.031)$ & $(0.018)$ \\
\hline
\end{tabular}

Each cell reports the parameter $\mu$, the discount rate wedge; i.e., the difference between the discount rate used by the firm in making intertemporal decisions and the risk-adjusted interest rate. Standard errors are in parentheses under the parameter estimates. Investment opportunities are measured using Tobin's q. Firms with Tobin's q above and below the median for the full sample are classifieds as having good and poor investment opportunities, respectively. 
Table 5

Sentiment and Investment Opportunities

Tobin's q - Adjusted for Misvaluation

\begin{tabular}{|l|c|c|c|c|}
\hline \multirow{2}{*}{} & \multicolumn{2}{|c|}{ Low sentiment } & \multicolumn{2}{c|}{ High sentiment } \\
\cline { 2 - 5 } & \multicolumn{2}{|c|}{ Investment Opportunities } & \multicolumn{2}{c|}{ Investment Opportunities } \\
\cline { 2 - 5 } & Good & Poor & Good & Poor \\
\hline Small & 0.085 & 0.006 & -0.006 & -0.069 \\
& $(0.029)$ & $(0.023)$ & $(0.020)$ & $(0.015)$ \\
\hline paying & 0.126 & 0.017 & 0.027 & -0.069 \\
\hline High volatility & $(0.014)$ & $(0.021)$ & $(0.014)$ & $(0.015)$ \\
\hline Young & 0.163 & -0.019 & 0.024 & -0.116 \\
& $(0.027)$ & $(0.036)$ & $(0.019)$ & $(0.023)$ \\
\hline Unprofitable & 0.124 & 0.018 & 0.000 & -0.077 \\
& $(0.019)$ & $(0.035)$ & $(0.020)$ & $(0.025)$ \\
\hline Low Earnings & 0.042 & 0.017 & -0.069 & -0.070 \\
& $(0.059)$ & $(0.054)$ & $(0.044)$ & $(0.034)$ \\
\hline Low Property, & 0.119 & 0.019 & -0.025 & -0.092 \\
Plant, and & $(0.034)$ & $(0.030)$ & $(0.029)$ & $(0.021)$ \\
Equipment & 0.078 & -0.054 & 0.009 & -0.100 \\
\hline High \& Low & $0.015)$ & $(0.031)$ & $(0.014)$ & $(0.023)$ \\
Book-to-Market & $(0.035)$ & $(0.036)$ & -0.011 & $(0.028)$ \\
\hline
\end{tabular}

Each cell reports the parameter $\mu$, the discount rate wedge; i.e., the difference between the discount rate used by the firm in making intertemporal decisions and the risk-adjusted interest rate. Standard errors are in parentheses under the parameter estimates. Investment opportunities are measured using Tobin's q adjusted for misvaluation. To partially adjust for potential misvaluation, firms with Tobin's q above and below the median for their industry and year are classifieds as having good and poor investment opportunities, respectively. 
Table 6

Sentiment and Investment Opportunities

Demand Shocks

\begin{tabular}{|l|c|c|c|c|}
\hline \multirow{2}{*}{} & \multicolumn{2}{|c|}{ Low sentiment } & \multicolumn{2}{c|}{ High sentiment } \\
\cline { 2 - 5 } & \multicolumn{2}{|c|}{ Investment Opportunities } & \multicolumn{2}{c|}{ Investment Opportunities } \\
\cline { 2 - 5 } & Good & Poor & Good & Poor \\
\hline Small & 0.101 & -0.019 & -0.007 & -0.126 \\
& $(0.032)$ & $(0.040)$ & $(0.026)$ & $(0.021)$ \\
\hline Non-Dividend- & 0.139 & 0.022 & 0.025 & -0.099 \\
Paying & $(0.017)$ & $(0.043)$ & $(0.017)$ & $(0.024)$ \\
\hline High Volatility & 0.196 & 0.018 & 0.017 & -0.141 \\
& $(0.033)$ & $(0.078)$ & $(0.027)$ & $(0.037)$ \\
\hline Young & 0.129 & 0.035 & -0.010 & -0.111 \\
& $(0.020)$ & $(0.065)$ & $(0.021)$ & $(0.038)$ \\
\hline Unprofitable & 0.080 & 0.005 & -0.053 & -0.135 \\
& $(0.071)$ & $(0.083)$ & $(0.049)$ & $(0.048)$ \\
\hline Low Earnings & 0.169 & 0.013 & -0.027 & -0.136 \\
& $(0.043)$ & $(0.051)$ & $(0.036)$ & $(0.029)$ \\
\hline Few Tangible & 0.089 & -0.068 & 0.009 & -0.107 \\
Assets & $(0.020)$ & $(0.045)$ & $(0.020)$ & $(0.029)$ \\
\hline High \& Low & 0.176 & -0.033 & 0.013 & -0.155 \\
Book-to-Market & $(0.046)$ & $(0.059)$ & $(0.037)$ & $(0.028)$ \\
\hline
\end{tabular}

Each cell reports the parameter $\mu$, the discount rate wedge; i.e., the difference between the discount rate used by the firm in making intertemporal decisions and the risk-adjusted interest rate. Standard errors are in parentheses under the parameter estimates. Investment opportunities are measured using demand shocks. Observations with real sales growth over the previous three years that is above the median for the full sample are classified as having received favorable demand shocks (i.e., as having good investment opportunities). 
Table 7

External Finance

Panel A: Low Sentiment Levels

\begin{tabular}{|c|c|c|c|}
\hline & $\begin{array}{c}\text { External } \\
\text { Finance }\end{array}$ & Equity & Debt \\
\hline Low sentiment & 0.092 & 0.044 & 0.048 \\
\hline Sensitive to sentiment & 0.101 & 0.052 & 0.049 \\
\hline Good investment opportunities & 0.175 & 0.080 & 0.095 \\
\hline Poor investment opportunities & 0.032 & 0.026 & 0.006 \\
\hline Insensitive to sentiment & 0.052 & 0.010 & 0.042 \\
\hline Good investment opportunities & 0.060 & 0.011 & 0.050 \\
\hline Poor investment opportunities & 0.041 & 0.008 & 0.033 \\
\hline
\end{tabular}

\section{Panel B: High Sentiment Levels}

\begin{tabular}{|c|c|c|c|}
\hline & $\begin{array}{c}\text { External } \\
\text { Finance }\end{array}$ & Equity & Debt \\
\hline High sentiment & 0.129 & 0.065 & 0.064 \\
\hline Sensitive to sentiment & 0.143 & 0.075 & 0.068 \\
\hline Good investment opportunities & 0.218 & 0.115 & 0.103 \\
\hline Poor investment opportunities & 0.072 & 0.038 & 0.034 \\
\hline Insensitive to sentiment & 0.054 & 0.010 & 0.044 \\
\hline Good investment opportunities & 0.064 & 0.011 & 0.052 \\
\hline Poor investment opportunities & 0.041 & 0.007 & 0.033 \\
\hline
\end{tabular}

Panel C: Low to High Sentiment - Percentage Change

\begin{tabular}{|c|c|c|c|}
\hline & $\begin{array}{c}\text { External } \\
\text { Finance }\end{array}$ & Equity & Debt \\
\hline Total & $40.7 \%$ & $48.7 \%$ & $33.7 \%$ \\
\hline Sensitive to sentiment & $41.2 \%$ & $44.6 \%$ & $37.9 \%$ \\
\hline Good investment opportunities & $24.5 \%$ & $43.4 \%$ & $8.6 \%$ \\
\hline Poor investment opportunities & $125.8 \%$ & $47.2 \%$ & $460.3 \%$ \\
\hline Insensitive to sentiment & $4.5 \%$ & $0.6 \%$ & $5.0 \%$ \\
\hline Good investment opportunities & $6.1 \%$ & $8.2 \%$ & $5.6 \%$ \\
\hline Poor investment opportunities & $-0.1 \%$ & $-13.1 \%$ & $2.5 \%$ \\
\hline
\end{tabular}

Each cell in Panels A and B contains the mean at the peak year (i.e., the year when the sentiment index is highest during a high sentiment episode and lowest during a low sentiment episode). 
External finance is the change in assets minus the change in retained earnings. Equity is the proceeds from new share issues. Debt is external finance minus equity. All are scaled by assets. Panel C reports the percentage change from Panel A (low sentiment) to Panel B (high sentiment). Investment opportunities are measured by Tobin's $Q$ adjusted for misvaluation. Sensitivity to sentiment is based on the characteristics in Table 2. 
Table 8

Low Sentiment

Sentiment-Sensitive Observations

\begin{tabular}{|l|c|}
\hline$\mu$ & 0.081 \\
& $(0.011)$ \\
\hline $\mathrm{N}$ & 71441 \\
\hline
\end{tabular}

The parameter $\mu$ is the discount rate wedge; i.e., the difference between the discount rate used by the firm in making intertemporal decisions and the risk-adjusted interest rate. Standard errors are in parentheses under the parameter estimate. The estimation method is described under Table 2, and sensitivity to sentiment is based on the characteristics in Table 2 . 
Table 9

Importance of Sentiment-Sensitive Observations

\begin{tabular}{|l|c|c|c|}
\hline & Full Sample & Low Sentiment & High Sentiment \\
\hline $\begin{array}{l}\text { Market } \\
\text { Capitalization }\end{array}$ & $49.44 \%$ & $45.55 \%$ & $52.16 \%$ \\
\hline Investment & $56.34 \%$ & $52.85 \%$ & $58.56 \%$ \\
\hline Capital Stock & $64.12 \%$ & $57.14 \%$ & $68.26 \%$ \\
\hline
\end{tabular}

The cell entries report the proportion of the variable accounted for by sentiment-sensitive observations. For example, the upper left cell reports the percentage of market capitalization accounted for by sentiment-sensitive observations. Sentiment-sensitive observations are defined in the same way as in Table 2. 
Table 10

Low Sentiment

Overall Effect on Discount Rate

\begin{tabular}{|l|c|}
\hline & Low Sentiment \\
\hline$\mu$ & 0.059 \\
& $(0.010)$ \\
\hline $\mathrm{N}$ & 71441 \\
\hline
\end{tabular}

The parameter $\mu$ is the discount rate wedge; i.e., the difference between the discount rate used by the firm in making intertemporal decisions and the risk-adjusted interest rate. The standard error is in parentheses under the parameter estimate. The estimation method is described under Table 2. 
Figure 1

Low Sentiment

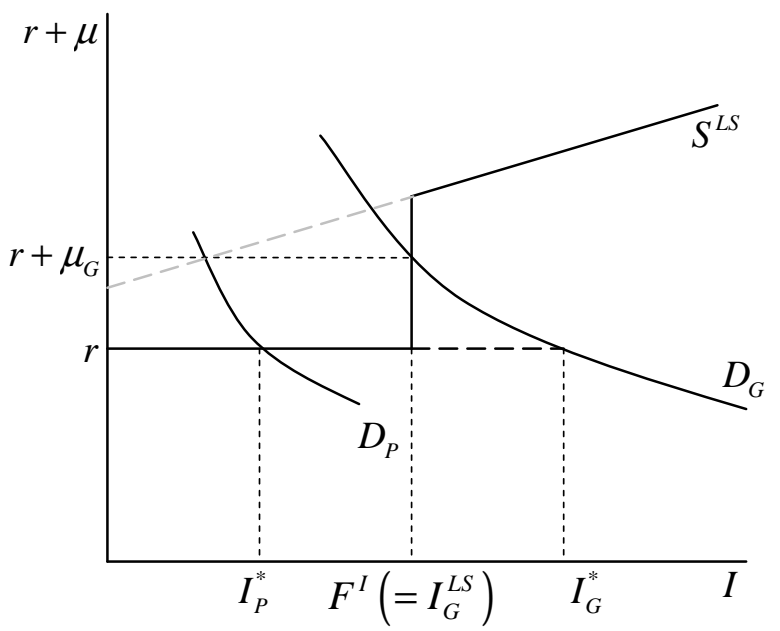

Figure 2

High Sentiment

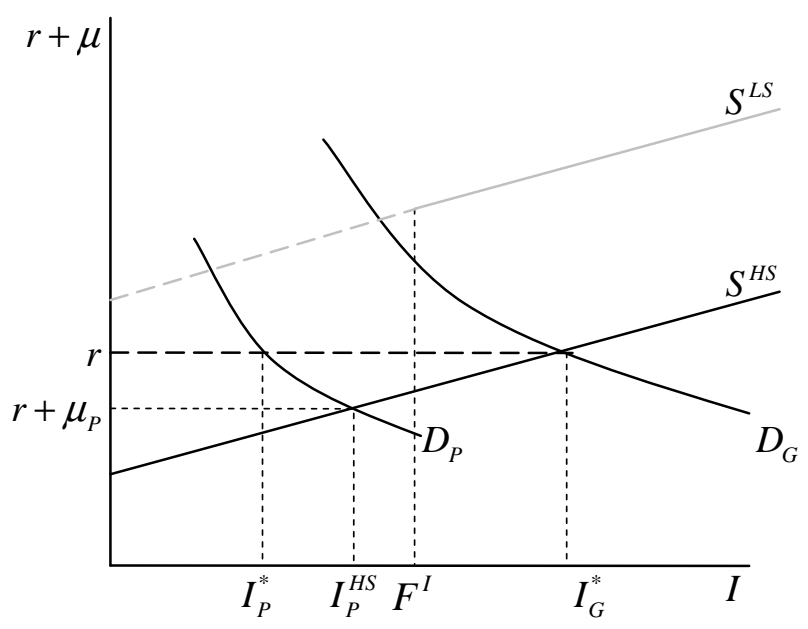

